\title{
An optimality-based model of the coupled soil moisture and root dynamics
}

\author{
S. J. Schymanski ${ }^{1, *}$, M. Sivapalan ${ }^{2, * *}$, M. L. $\operatorname{Roderick}^{3}$, J. Beringer ${ }^{4}$, and L. B. Hutley ${ }^{5}$ \\ ${ }^{1}$ School of Environmental Systems Engineering, The University of Western Australia, Australia \\ ${ }^{2}$ Centre for Water Research, The University of Western Australia, Australia \\ ${ }^{3}$ Environmental Biology Group, Research School of Biological Sciences and Research School of Earth Sciences, The \\ Australian National University, Canberra, Australia \\ ${ }^{4}$ School of Geography and Environmental Science, Monash University, Australia \\ ${ }^{5}$ School of Science \& Primary Industries, Charles Darwin University, Australia \\ *now at: Max Planck Institute for Biogeochemistry, Postfach 1001 64, 07701 Jena, Germany \\ ** now at: Dept. of Geography and Civil and Environmental Engineering, University of Illinois at Urbana-Champaign, USA
}

Received: 22 November 2007 - Published in Hydrol. Earth Syst. Sci. Discuss.: 9 January 2008

Revised: 14 May 2008 - Accepted: 20 May 2008 - Published: 17 June 2008

\begin{abstract}
The main processes determining soil moisture dynamics are infiltration, percolation, evaporation and root water uptake. Modelling soil moisture dynamics therefore requires an interdisciplinary approach that links hydrological, atmospheric and biological processes. Previous approaches treat either root water uptake rates or root distributions and transpiration rates as given, and calculate the soil moisture dynamics based on the theory of flow in unsaturated media. The present study introduces a different approach to linking soil water and vegetation dynamics, based on vegetation optimality. Assuming that plants have evolved mechanisms that minimise costs related to the maintenance of the root system while meeting their demand for water, we develop a model that dynamically adjusts the vertical root distribution in the soil profile to meet this objective. The model was used to compute the soil moisture dynamics, root water uptake and fine root respiration in a tropical savanna over 12 months, and the results were compared with observations at the site and with a model based on a fixed root distribution. The optimality-based model reproduced the main features of the observations such as a shift of roots from the shallow soil in the wet season to the deeper soil in the dry season and substantial root water uptake during the dry season. At the same time, simulated fine root respiration rates never exceeded the upper envelope determined by the observed soil
\end{abstract}

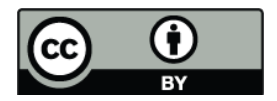

Correspondence to: S. J. Schymanski (sschym@bgc-jena.mpg.de) respiration. The model based on a fixed root distribution, in contrast, failed to explain the magnitude of water use during parts of the dry season and largely over-estimated root respiration rates. The observed surface soil moisture dynamics were also better reproduced by the optimality-based model than the model based on a prescribed root distribution. The optimality-based approach has the potential to reduce the number of unknowns in a model (e.g. the vertical root distribution), which makes it a valuable alternative to more empirically-based approaches, especially for simulating possible responses to environmental change.

\section{Introduction}

The weakest component of soil-vegetation-atmosphere transfer (SVAT) models is their link with the soil environment (Feddes et al., 2001). Therefore, improvements in our understanding and parameterisation of root water uptake are necessary to increase our confidence in the outputs of global circluation models (GCM) that depend on accurate estimates of vegetation water use. Typically, SVAT models within numerical weather prediction and climate models do a poor job at simulating soil moisture dynamics, which in turn means that the fluxes of water and heat to the atmosphere are also poorly represented. Improving this is therefore also a priority to advance weather forecasting (Giard and Bazile, 2000). Processbased models of soil moisture dynamics usually consider root

Published by Copernicus Publications on behalf of the European Geosciences Union. 
water uptake by adding a sink term to Richards' equation. This sink term typically depends on the description of an "effective root-density distribution" of varying complexity and other variables (Varado et al., 2006). The choice of vertical distributions of roots in the soil profile can affect the vertical distribution of soil moisture and transpiration rates simulated by models (Feddes et al., 2001). Feddes et al. (2001) therefore suggest that detailed observations of root profiles within different biomes at the global scale may be necessary for improved parameterisation of root water uptake in models and ultimately for improving the predictions of GCMs. A number of such observations have been compiled by Jackson et al. (1997).

However, the necessary pooling of observations within and across sites masks the important spatial and temporal dynamics within a biome (Jackson et al., 1997). It is known that root distributions can be very dynamic, especially in savannas. For example, Chen et al. (2004) have shown for a tropical savanna that the active root distribution can change from being shallow to deeper root dominated within a couple of months. The observed seasonal variation of root abundance within the top meter of soil was one order of magnitude (Chen et al., 2002), presumably due to the dynamic nature of the tree-grass interactions. The dynamics of root systems are also reviewed in Schenk (2005). Prescribing static root profiles, or even empirically-based root growth algorithms, is particularly problematic if the model is intended to be used for the prediction of responses to long-term environmental change. Jackson et al. (2000) pointed out that the belowground changes associated with environmental change can have large impacts on biogeochemical cycles and neglecting this can lead to substantial errors in model outputs.

Models exploring the assumption that vegetation is optimally adapted to its environment are an alternative to models based on prescribed vegetation properties (Raupach, 2005). The optimal water use hypothesis (Cowan and Farquhar, 1977), for example, is useful for predicting the diurnal and day-to-day dynamics of water use if the photosynthetic properties of the vegetation and its monthly water use are known (Schymanski et al., 2008). Another study explored the assumption that natural vegetation self-organises in a way to maximise its net carbon profit (i.e. the difference between carbon acquired by photosynthesis and carbon spent on the maintenance of the organs involved in its uptake) (Schymanski et al., 2007). The model was able to reproduce the observed above-ground leaf area index and photosynthetic properties of a savanna vegetation given the observed water use and meteorological data, without prescribing any sitespecific vegetation properties during the wet season (Schymanski et al., 2007). However, this model did not consider the costs for the uptake and transport of water and therefore it was not able to predict the water use itself or the vegetation cover during the dry season, when the below-ground costs would have been more important than during the wet season (Schymanski et al., 2007). Therefore, an optimality- based model of root water uptake, quantifying the costs and benefits of the root system, is needed to take the vegetation optimality approach one step further and implement it for the whole plant system in coupled ecohydrological models.

The distinct advantage of optimality-based models is that they simulate the adaptation of vegetation to given environmental conditions and, in theory, do not rely on parameter tuning. Therefore, they are particularly well suited for predicting the long-term effects of environmental change, when it can be assumed that vegetation has adapted to the new conditions. Optimality approaches have been explored previously for modelling root water uptake (e.g. Kleidon and Heimann, 1996, 1998; van Wijk and Bouten, 2001; Laio et al. , 2006; Collins and Bras, 2007), but we are only aware of one that modelled a dynamically adapting root distribution (Kleidon and Heimann, 1996). However, the resulting model was deemed impractical for implementation into coupled biogeochemical or ecohydrological models due to its large computational demands.

The aim of this study is to present and test an optimalitybased model relating root water uptake to carbon costs that is simple enough to be implemented into a coupled ecohydrological model allowing for simultaneous optimisation of above- and below-ground vegetation. To test the model, we used the same data set as Schymanski et al. (2007, 2008), where the optimality approach has been applied previously to model the above-ground vegetation properties of a tropical savanna. This time, the root system was optimised to meet the observed canopy water demand while minimising the root maintenance costs. The observations available for comparison with model outputs were the dynamics of surface soil moisture, evapo-transpiration rates and below-ground respiration. As this study primarily focuses on fine root water uptake, a realistic simulation of transpiration and root respiration rates was taken as the main benchmark for model performance.

For comparison with the conventional approach to modelling root water uptake, the same model was also run with a prescribed root profile, which is considered to be typical for a humid tropical savanna (Schenk and Jackson, 2002; Jackson et al., 1997). Model parameters were taken from the literature, or, where not available, reasonable values were prescribed without parameter tuning. Given that the optimalitybased model does not require any input about the root surface area on the site, we consider the model useful if it does not lead to a significantly worse correspondence between the model results and observations than the model based on a prescribed root profile.

\section{Methods}

In the following, we describe the soil water balance model used for calculating the soil water fluxes, the vegetation water balance model used for calculating root water uptake and 
the root optimisation algorithm separately. The soil water balance model calculates the soil moisture distribution within the soil profile, the position of the water table and the spontaneous flow of water in a conceptual lumped catchment, including infiltration during rainfall and ex-filtration into the channel. The vegetation water balance model simulates the water storage within the vegetation (e.g. water storage in tree trunks) and the root suction as a function of this water storage. Due to the explicit consideration of the water storage within the vegetation tissues, the model allows simulation of root water uptake during the night when no transpiration occurs and investigation of phenomena such as hydraulic redistribution by plant roots (Burgess et al., 1998; Meinzer et al., 2001). The purpose of the root optimisation algorithm was to simulate dynamic adaptation of the root system to the water availability in the soil profile and the water demand by the canopy.

\subsection{Water balance model}

To account for the transfer of water between the atmosphere, soil and the river channel, we initially followed the "Representative Elementary Watershed" (REW) approach formulated by Reggiani et al. (2000), but extended it to allow the calculation of the vertical distribution of water within the unsaturated zone and adjusted some of the closure relations to be consistent with our formulation. For simplicity, interactions between elementary watersheds and streamflow routing were neglected, so that all water reaching the channel was assumed to be instantaneous runoff.

In the REW model, an elementary watershed is subdivided into two soil layers, the saturated and unsaturated layer, both of variable thickness. The thickness of each zone and all fluxes are spatially averaged (divided by the catchment area), so that the model can be summarised with just a few variables (Reggiani et al., 2000): the average bedrock elevation from reference datum $\left(z_{s}, \mathrm{~m}\right)$, the average channel elevation from reference datum $\left(z_{r}, \mathrm{~m}\right)$, the average depth of the pedosphere $(Z, \mathrm{~m})$, the average thickness of the saturated zone $\left(y_{s}, \mathrm{~m}\right)$, the average thickness of the unsaturated zone $\left(y_{u}, \mathrm{~m}\right)$, the average saturation degree in the unsaturated zone $\left(s_{u}\right)$, the unsaturated surface area fraction $\left(\omega_{u}\right)$ and the saturated surface area fraction contributing to seepage face and overland flow $\left(\omega_{o}\right)$. See Fig. 1 for a diagram of a simplified REW. For simplicity, we set the datum to coincide with the average bedrock elevation, so that $z_{s}=0 \mathrm{~m}$. Any fluxes into and out of the saturated zone $\left(Q_{u}, Q_{s f}\right.$ or $\left.E_{T s}, \mathrm{~m}^{3} \mathrm{~m}^{-2} \mathrm{~s}^{-1}=\mathrm{m} \mathrm{s}^{-1}\right)$ lead to changes in the thickness of both the saturated and the unsaturated zones, and also to changes in the unsaturated and saturated surface area fractions if $y_{s}>z_{r}$. The relationships between $y_{s}, y_{u}, \omega_{u}$ and $\omega_{o}$ depend on the geometry of the catchment and are given for linear hillslopes in this study, where $\omega_{u}$ and $y_{u}$ are both calculated as a function of $y_{s}$ (for

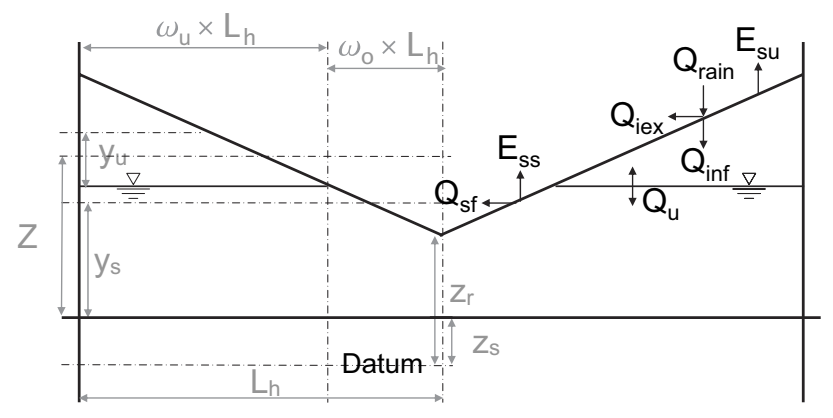

Fig. 1. Cross-section of a simplified elementary watershed. Variables on the left hand side (in grey) denote spatial dimensions (see text), while the variables on the right hand side denote water fluxes (precipitation ( $\left.Q_{\text {rain }}\right)$, infiltration ( $\left.Q_{\text {inf }}\right)$, infiltration excess runoff $\left(Q_{\text {iex }}\right)$, soil evaporation from the saturated zone and the unsaturated zone ( $E_{S s}$ and $E_{s u}$ respectively), flow between saturated and unsaturated layer $\left(Q_{u}\right)$ and outflow across the seepage face $\left(Q_{s f}\right)$.

a derivation, see Appendix A.3.2.1 in Schymanski, 2007):

$\omega_{u}= \begin{cases}\frac{Z-y_{s}}{\sqrt{\left(Z-y_{s}\right)\left(Z-z_{r}\right)}} & y_{s}>z_{r} \\ 1 & y_{s} \leq z_{r}\end{cases}$

and

$y_{u}= \begin{cases}\sqrt{\left(Z-y_{s}\right)\left(Z-z_{r}\right)} & y_{s}>z_{r} \\ Z-y_{s} & y_{s} \leq z_{r}\end{cases}$

The saturated surface area fraction $\left(\omega_{o}\right)$ is the complement of $\omega_{u}$. The above relations can be used to calculate $\omega_{o}, \omega_{u}$ and $y_{u}$ for any given values of $Z, z_{r}$ and $y_{s}$ in a linear hillslope.

\subsubsection{Vertical subdivision of the unsaturated zone}

In the original REW model, the unsaturated zone was treated as a lumped volume, but for the purpose of this study, the unsaturated zone was subdivided into several layers and soil moisture was calculated for each layer separately. Starting from the top of the unsaturated zone, we divided the unsaturated zone into soil layers of prescribed thickness $\delta_{y u \text { min }}$ (in this study $0.1 \mathrm{~m}$ ), until we reached the groundwater table. The soil layer adjacent to the water table was the only layer with differing thickness, which we set to a value between $\delta_{y u \text { min }}$ and $2 \times \delta_{y u \text { min }}$ to reflect the total thickness of the unsaturated zone $\left(y_{u}\right)$. The number of soil layers in the unsaturated zone ( $\left.n_{\text {layers }}\right)$ was equivalent to the lower integer value of $y_{u} / \delta_{y u \min }$.

\subsubsection{Soil water fluxes}

Water fluxes between different soil layers were calculated using a discretisation of the Buckingham-Darcy Equation (Radcliffe and Rasmussen, 2002), which is the 1-D equivalent of Richards' equation for steady flow. All fluxes were 
Table 1. Symbols used in this study and their units. Values in curly brackets indicate ranges of values allowed in this study. If not stated otherwise in this table, addition of the subscript $i, 1$, or nlayers to a symbol in the main text denotes reference to soil layer $i$, the top soil layer or the bottom soil layer of the unsaturated zone respectively. Addition of the subscript $p$ or $s$ refers to the perennial or seasonal vegetation component respectively.

\begin{tabular}{|c|c|c|}
\hline Symbol & Description & Value / Units \\
\hline$\alpha_{v G}$ & Empirical parameter of the van Genuchten water retention model & $7.5 \mathrm{~m}^{-1}$ \\
\hline$\gamma_{0}$ & Average slope angle of the seepage face & $1.9^{\circ}$ \\
\hline$\delta_{y u}$ & Thickness of a soil layer & $\{0.1-0.2\} \mathrm{m}$ \\
\hline$\delta_{y u \min }$ & Minimum thickness of soil layers & $0.1 \mathrm{~m}$ \\
\hline$\varepsilon$ & Soil porosity $\left(\varepsilon=\theta_{s}-\theta_{r}\right)$ & $0.245 \mathrm{~m}^{3} \mathrm{~m}^{-3}$ \\
\hline$\Lambda_{S}$ & Typical horizontal length scale for seepage face flow & $10.0 \mathrm{~m}$ \\
\hline$\rho_{w}$ & Density of water & $1000 \mathrm{~kg} \mathrm{~m}^{-3}$ \\
\hline$\theta$ & Volumetric soil water content & $\mathrm{m}^{3} \mathrm{~m}^{-3}$ \\
\hline$\theta_{r}$ & Residual soil water content & $0.065 \mathrm{~m}^{3} \mathrm{~m}^{-3}$ \\
\hline$\theta_{s}$ & Saturated soil water content & $0.31 \mathrm{~m}^{3} \mathrm{~m}^{-3}$ \\
\hline$\omega_{o}$ & Saturated surface area fraction & $\{0.0-1.0\}$ \\
\hline$\omega_{u}$ & Unsaturated surface area fraction & $\{0.0-1.0\}$ \\
\hline$\Omega_{r}$ & Root resistivity to water uptake per unit root surface area & $1.02 \times 10^{8} \mathrm{~s}$ \\
\hline$\Omega_{s}$ & Resistivity to water flow towards the roots in the soil & $\mathrm{s}$ \\
\hline$c_{1}$ & Empirical constant used in Eq. 23 & 750 bar \\
\hline$c_{2}$ & Empirical constant used in Eq. 23 & 1 bar \\
\hline$c_{P b m}$ & $\begin{array}{l}\text { Conversion coefficient to convert from pressure (bar) } \\
\text { to hydraulic head }(\mathrm{m}) \text {. }\end{array}$ & $10.2 \mathrm{~m} \mathrm{bar}^{-1}$ \\
\hline$c_{R r}$ & Root respiration rate per unit fine root volume & $0.0017 \mathrm{~mol} \mathrm{~m}^{-3} \mathrm{~s}-1$ \\
\hline$E_{S}$ & Soil evaporation per unit horizontal catchment area & $\mathrm{m} \mathrm{s}^{-1}$ \\
\hline$E_{s s}$ & $\begin{array}{l}\text { Soil evaporation from the saturated zone } \\
\text { per unit horizontal catchment area }\end{array}$ & $\mathrm{m} \mathrm{s}^{-1}$ \\
\hline$E_{s u}$ & $\begin{array}{l}\text { Soil evaporation from the unsaturated zone } \\
\text { per unit horizontal catchment area }\end{array}$ & $\mathrm{m} \mathrm{s}^{-1}$ \\
\hline$E_{T s}$ & $\begin{array}{l}\text { Evapo-transpiration rate from the saturated zone } \\
\text { per unit horizontal catchment area }\end{array}$ & $\mathrm{m} \mathrm{s}^{-1}$ \\
\hline$G_{r \max }$ & Maximum daily increment in $S_{A d r, i}$ & $0.1 \mathrm{~m}^{2} \mathrm{~m}^{-3} \mathrm{~d}^{-1}$ \\
\hline$G_{\text {Soil }}$ & Conductivity of the soil to water vapour flux & $0.03 \mathrm{~mol} \mathrm{~m}^{-2} \mathrm{~s}^{-1}$ \\
\hline$h$ & Suction head in the soil matrix & $\mathrm{m}$ \\
\hline$h_{h, i}$ & $\begin{array}{l}\text { Hydrostatic head difference between the soil surface } \\
\text { and the depth of layer } i\end{array}$ & $\mathrm{~m}$ \\
\hline$h_{r}$ & Root suction head & $\mathrm{m}$ \\
\hline$J_{r}$ & Water uptake per unit root surface area & $\mathrm{m} \mathrm{s}^{-1}$ \\
\hline$J_{r \text { daily }}$ & Daily root water uptake per unit root surface area & $\mathrm{m} \mathrm{d}^{-1}$ \\
\hline$k_{r}$ & Coefficient of root optimisation & $-1.0<k_{r}<1.0$ \\
\hline$k_{r \text { eff }}$ & Relative effectiveness of fine roots & $\{0.0-1.0\}$ \\
\hline$K_{\text {Sat }}$ & Saturated hydraulic conductivity & $1.23 \times 10^{-5} \mathrm{~m} \mathrm{~s}^{-1}$ \\
\hline$K_{\text {unsat }}$ & Unsaturated hydraulic conductivity & $\mathrm{m} \mathrm{s}^{-1}$ \\
\hline
\end{tabular}

averaged over the catchment area (see Appendix A.3.2.2 in Schymanski (2007) for their derivations). The flux between layer $i$ and layer $i+1$ was calculated as:

$$
Q_{i}=\omega_{u} \frac{K_{\text {unsat }, i}+K_{\text {unsat }, i+1}}{2}\left(\frac{h_{i}-h_{i+1}}{0.5\left(\delta_{y u, i}+\delta_{y u, i+1}\right)}-1\right)
$$

where $h(\mathrm{~m})$ is the "matric suction head" and $K_{\text {unsat }}\left(\mathrm{m} \mathrm{s}^{-1}\right)$ the unsaturated hydraulic conductivity. The subscript $i$ denotes the $i$ th layer, $Q_{i}\left(\mathrm{~ms}^{-1}\right)$ denotes the flux across the bottom boundary of layer $i$ and $\delta_{y u, i}(\mathrm{~m})$ denotes the thickness of layer $i$. In the present work, $h$ with units of hydraulic pressure head (m), is defined as positive and increases with decreasing soil saturation. $Q_{i}$ is defined as positive if water flows upwards and negative if it flows downwards. 
Table 1. Continued.

\begin{tabular}{|c|c|c|}
\hline Symbol & Description & Value / Units \\
\hline$M_{d}$ & Mass of dry matter in living plant tissues per unit ground area & $3.1 \mathrm{~kg} \mathrm{~m}^{-2}$ \\
\hline$m_{v G}$ & $\begin{array}{l}\text { Empirical parameter of the van Genuchten } \\
\text { water retention model }\end{array}$ & 0.47 \\
\hline$M_{q}$ & $\begin{array}{l}\text { Mass of liquid matter in living plant tissues } \\
\text { per unit ground area }\end{array}$ & $\mathrm{kg} \mathrm{m}^{-2}$ \\
\hline$M_{q \min }$ & $\begin{array}{l}\text { Daily minimum of liquid matter in living plant tissues } \\
\text { per unit ground area }\end{array}$ & $\mathrm{kg} \mathrm{m}^{-2}$ \\
\hline$M_{q x}$ & $\begin{array}{l}\text { Water storage capacity of living plant tissues } \\
\text { per unit ground area }\end{array}$ & $3.1 \mathrm{~kg} \mathrm{~m}^{-2}$ \\
\hline$M_{w}$ & Molar weight of water & $0.018 \mathrm{~kg} \mathrm{~mol}^{-1}$ \\
\hline$n_{\text {layers }}$ & Number of soil layers in the unsaturated zone & integer \\
\hline$n_{v G}$ & $\begin{array}{l}\text { Empirical parameter of the van Genuchten } \\
\text { water retention model }\end{array}$ & 1.89 \\
\hline$P_{b}$ & $\begin{array}{l}\text { Balance pressure of a plant organ, } \\
\text { measured by the pressure bomb }\end{array}$ & bar \\
\hline$Q$ & $\begin{array}{l}\text { Flow rate across the bottom boundary of a soil layer per unit } \\
\text { horizontal catchment area (positive in upwards direction) }\end{array}$ & $\mathrm{m} \mathrm{s}^{-1}$ \\
\hline$Q_{\text {inf }}$ & Infiltration rate per unit horizontal catchment area & $\mathrm{m} \mathrm{s}^{-1}$ \\
\hline$Q_{\text {out }}$ & Immediate runoff per unit catchment area & $\mathrm{m} \mathrm{s}^{-1}$ \\
\hline$Q_{r}$ & Root water uptake per unit horizontal catchment area & $\mathrm{m} \mathrm{s}^{-1}$ \\
\hline$Q_{\text {rain }}$ & Precipitation rate per unit horizontal catchment area & $\mathrm{m} \mathrm{s}^{-1}$ \\
\hline$Q_{s f}$ & $\begin{array}{l}\text { Flow rate across the seepage face } \\
\text { per unit horizontal catchment area }\end{array}$ & $\mathrm{m} \mathrm{s}^{-1}$ \\
\hline$Q_{u}$ & $\begin{array}{l}\text { Drainage from the unsaturated zone } \\
\text { per unit horizontal catchment area }\left(=Q_{\text {nlayers }}\right)\end{array}$ & $\mathrm{m} \mathrm{s}^{-1}$ \\
\hline$r_{r}$ & Mean radius of fine roots & $0.3 \times 10^{-3} \mathrm{~m}$ \\
\hline$R_{r}$ & Root respiration rate per unit ground area & $\mathrm{mol} \mathrm{m}^{-2} \mathrm{~s}^{-1}$ \\
\hline$S_{A d r}$ & Root surface area density (root surface area per unit soil volume) & $\mathrm{m}^{2} \mathrm{~m}^{-3}$ \\
\hline$S_{A r}$ & Root surface area per unit ground area & $\mathrm{m}^{2} \mathrm{~m}^{-2}$ \\
\hline$s_{u}$ & Average saturation degree in the unsaturated zone & $0-1.0$ \\
\hline$t$ & $\begin{array}{l}\text { Time, whith numerical subscripts } \\
\text { denoting consecutive points in time }\end{array}$ & $\mathrm{s}$ \\
\hline$W_{a}$ & Mole fraction of water vapour in the atmosphere & $\mathrm{mol} \mathrm{mol}^{-1}$ \\
\hline$w_{c}$ & Total water store of the soil domain per unit catchment area & $\mathrm{m}$ \\
\hline$w_{s}$ & Water store per unit catchment area & $\mathrm{m}$ \\
\hline$W_{S}$ & $\begin{array}{l}\text { Mole fraction of water in the laminar air layer } \\
\text { immediately above the soil }\end{array}$ & mol mol ${ }^{-1}$ \\
\hline$y_{S}$ & Average thickness of the saturated zone & $\mathrm{m}$ \\
\hline$y_{u}$ & Average thickness of the unsaturated zone & $\mathrm{m}$ \\
\hline$Z$ & Average depth of the pedosphere & $\mathrm{m}$ \\
\hline$z_{s}$ & Average bedrock elevation from reference datum & $0.0 \mathrm{~m}$ \\
\hline
\end{tabular}




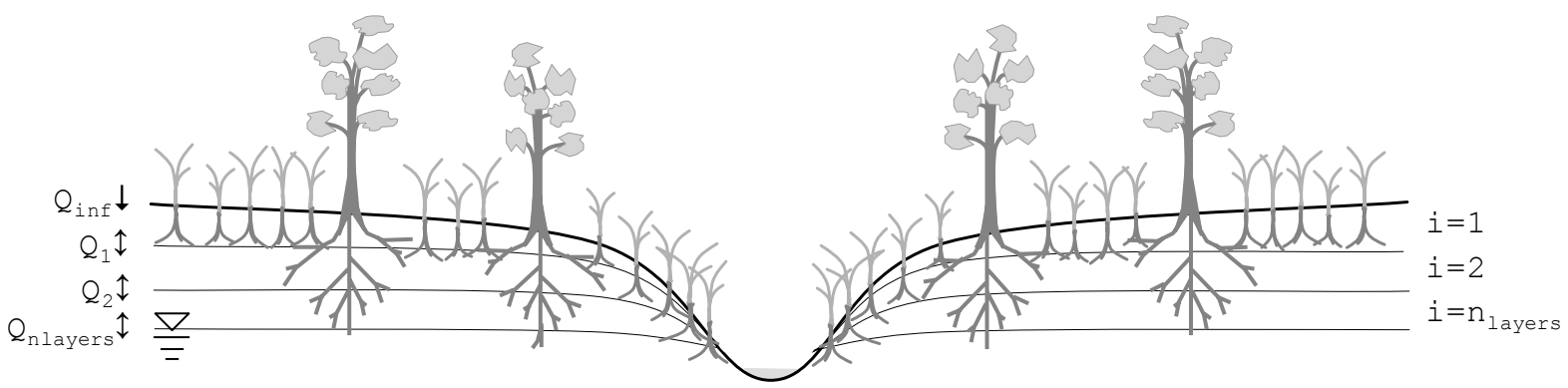

Fig. 2. Conceptual catchment, with the unsaturated zone subdivided into three soil layers. Soil layers are given indices $\left(i=1 \ldots n_{\text {layers }}\right)$, starting with 1 at the soil surface (right). The indices relating to fluxes refer to fluxes across the bottom boundary of the respective layer (left).

In the saturated zone, the hydraulic conductivity is $K_{\text {sat }}$ (taken as $1.23 \times 10^{-5} \mathrm{~m} \mathrm{~s}^{-1}$ for sandy loam) and the matric suction head $(h)$ is assumed to be $0 \mathrm{~m}$, so that the flux across the boundary between the unsaturated and the saturated zone was written as:

$Q_{\text {nlayers }}=\omega_{u} \frac{K_{\text {unsat }, i}+K_{\text {sat }}}{2}\left(\frac{h_{i}}{0.5 \delta_{y u, i}}-1\right)$

The above equations require the calculation of matric suction head $\left(h_{i}\right)$ and unsaturated hydraulic conductivity $\left(K_{\text {unsat,i }}\right)$ in each soil layer at each time step. These were obtained as a function of the soil saturation degree $\left(s_{u, i}\right)$, from the widely used water retention model formulated by van Genuchten (1980):

$h_{i}=\frac{1}{\alpha_{v G}}\left(s_{u, i}^{-\frac{1}{m_{v G}}}-1\right)^{\frac{1}{n_{v G}}}$

and

$K_{\text {unsat }, \mathrm{i}}=K_{\mathrm{sat}} \sqrt{s_{u, i}}\left(1-\left(1-s_{u, i}^{\frac{1}{m_{v G}}}\right)^{m_{v G}}\right)^{2}$

The parameters $\alpha_{v G}\left(\mathrm{~m}^{-1}\right), n_{v G}$ and $m_{v G}$ have to be fitted to empirical soil water retention curves, and the saturated hydraulic conductivity $\left(K_{\text {sat }} \mathrm{m} \mathrm{s}^{-1}\right)$ is also an empirical constant, specific for a given soil type. Standard values for different soil types can be found in the literature, where $n_{v G}$ and $m_{v G}$ are usually assumed to follow the relation (van Genuchten, 1980):

$m_{v G}=1-\frac{1}{n_{v G}}$

The soil saturation degree $\left(s_{u, i}\right)$ itself is a function of the volumetric water content $\left(\theta_{i}\right)$ and the empirical soil properties $\theta_{r}$ and $\theta_{s}$ (van Genuchten, 1980):

$s_{u, i}=\frac{\theta_{i}-\theta_{r}}{\theta_{s}-\theta_{r}}$
The parameter values of the saturated hydraulic conductivity $\left(K_{\text {sat }} \mathrm{m} \mathrm{s}^{-1}\right), \alpha_{v g}, n_{v G}$ and $\theta_{r}$ were taken from the software package Hydrus 1-D (Simunek et al., 2005) as typical values given for sandy loam $\left(K_{\mathrm{sat}}=1.23 \times 10^{-5} \mathrm{~m} \mathrm{~s}^{-1}\right.$, $\alpha_{v g}=7.5 \mathrm{~m}^{-1}, n_{v G}=1.89, \theta_{r}=0.065 \mathrm{~m}^{3} \mathrm{~m}^{-3}$ ), while $\theta_{s}$ was adapted to reflect the highest measured soil water content in the data set $\left(\theta_{s}=0.31 \mathrm{~m}^{3} \mathrm{~m}^{-3}\right)$. The parameterisation was the same for all soil layers.

\subsubsection{Infiltration and runoff}

Interception of rainfall by the vegetation was neglected in this study, so that all rainfall was assumed to hit the ground. Interception effects are expected to be relatively small at the study site, mainly because rainfall events tend to be large relative to the size of canopy storage. For application of the model to sites where interception is expected to play a larger role, it could be included by replacing the rainfall rate ( $Q_{\text {rain }}$, $\mathrm{m} \mathrm{s}^{-1}$ ) in Eq. (9) by the throughfall rate after interception. In the present study, consideration of interception would have led to a slight delay of infiltration, rather than a substantial reduction of the simulated infiltration.

Infiltration was assumed to only occur into the unsaturated zone. The infiltration capacity was expressed by imagining an infinitely thin layer of water above the top soil layer and expressing the infiltration capacity as $Q_{i}$ for $i=0$, where $K_{\text {unsat }, i}$ is replaced by $K_{\mathrm{sat}}, h_{i}$ by $0 \mathrm{~m}$, and $\delta_{y u, i}$ by $0 \mathrm{~m}$ in Eq. (3). The rate of infiltration $\left(Q_{\text {inf }}, \mathrm{m} \mathrm{s}^{-1}\right)$ was then formulated as the lesser of infiltration capacity and rainfall intensity $\left(Q_{\text {rain }}, \mathrm{m} \mathrm{s}^{-1}\right)$ :

$Q_{\text {inf }}=\min \left(\omega_{u} K_{\mathrm{sat}}\left(\frac{h_{1}}{0.5 \delta_{y u, 1}}+1\right), \omega_{u} Q_{\text {rain }}\right)$

Rainfall exceeding $Q_{\text {inf }}$ was assumed to contribute to immediate runoff $\left(Q_{\text {out }}, \mathrm{m} \mathrm{s}^{-1}\right)$. In the presence of a seepage face (i.e. when $y_{s}>z_{r}$ ), flow across the seepage face also 
contributed to runoff. We calculated the seepage face flow $\left(Q_{s f}, \mathrm{~m} \mathrm{~s}^{-1}\right)$ following Reggiani et al. (2000):

$Q_{s f}=\frac{K_{\mathrm{sat}}\left(y_{s}-z_{r}\right) \omega_{o}}{2 \cos \left(\gamma_{0}\right) \Lambda_{s}}$

The parameter $\gamma_{0}$ is the average slope angle of the seepage face (set to 0.033 radians ( $=1.9$ degrees) in this study), while $\Lambda_{s}$ is a typical horizontal length scale, which depends on the length of the hillslope. In the absence of a more rigorous treatment of this parameter, we followed the approach by Reggiani et al. (2000) and set the parameter value to $\Lambda_{s}=10 \mathrm{~m}$. It is obvious from Eq. (10) that a larger value of $\Lambda_{s}$ would have the same effect as a smaller value of $\gamma_{0}$, i.e. a reduction of $Q_{s f}$.

The total runoff summed to:

$$
Q_{\text {out }}=Q_{\text {rain }}+Q_{s f}-Q_{\text {inf }}
$$

\subsubsection{Evaporative fluxes}

Figure 1 included two other fluxes: the soil evaporation from the unsaturated zone $\left(E_{s u}, \mathrm{~m} \mathrm{~s}^{-1}\right)$ and from the saturated zone $\left(E_{s s}, \mathrm{~m} \mathrm{~s}^{-1}\right)$. For the layered model (Fig. 2), we have to distinguish between soil evaporation, which occurs at the soil-air interface only, and transpiration by vegetation, which is linked to root water uptake $\left(Q_{r, i}\right)$ from all layers within the rooting zone. Root water uptake is described in Sect. 2.2, so only equations for soil evaporation are presented here.

Soil evaporation $\left(E_{s}, \mathrm{~m} \mathrm{~s}^{-1}\right)$ was modelled using a fluxgradient approach:

$$
E_{s}=\frac{M_{w}}{\rho_{w}} G_{\text {soil }}\left(W_{s}-W_{a}\right)
$$

where $W_{s}$ denotes the mole fraction of water in the laminar air layer immediately above the soil, and $W_{a}$ the mole fraction of water in the atmosphere, while $G_{\text {soil }}\left(\mathrm{mol} \mathrm{m}^{-2} \mathrm{~s}^{-1}\right)$ is the conductivity of the soil to water vapour fluxes. The molar weight of water $\left(M_{w}, 0.018 \mathrm{~kg} \mathrm{~mol}^{-1}\right)$ and the density of water $\left(\rho_{w}\right.$, set to $1000 \mathrm{~kg} \mathrm{~m}^{-3}$, irrespective of the temperature) were used to convert from molar units $\left(\mathrm{mol} \mathrm{m}^{-2} \mathrm{~s}^{-1}\right)$ to volumetric units of liquid water $\left(\mathrm{m}^{3} \mathrm{~m}^{-2} \mathrm{~s}^{-1}=\mathrm{m} \mathrm{s}^{-1}\right)$.

The formulation is equivalent to common soil evaporation models (Lee and Pielke, 1992) if $G_{\text {soil }}$ is set to the product of the moisture transfer coefficient and wind speed. $W_{s}$ was calculated as the vapour pressure in the laminar layer immediately above the soil $\left(p_{v s}\right)$ divided by air pressure. $p_{v s}$ was modelled as a function of the atmospheric vapour pressure, the saturation vapour pressure at the measured soil temperature, modelled volumetric soil moisture in the top soil layer and volumetric soil moisture at field capacity at the site (Lee and Pielke, 1992).

The value for soil moisture at field capacity for the site was set to 0.156 , equivalent to the soil moisture at a matric suction head $(h)$ of $1.0 \mathrm{~m}$ (Kelley, 2002). In the absence of data about near-soil wind speeds, the parameter $G_{\text {soil }}$ in Eq. (12) was set to the constant value of $0.03 \mathrm{~mol} \mathrm{~m}^{-2} \mathrm{~s}^{-1}$, which led to reasonable soil evaporation rates on the site (Schymanski et al., 2007; Schymanski, 2007). $E_{s}$ was calculated for the unsaturated and the saturated zones separately, and multiplied by their respective surface area fractions to obtain $E_{s u}$ and $E_{s s}$.

\subsubsection{Conservation of mass}

Changes in the state variables $s_{u, i}, \delta_{y u, i}, \omega_{o}, \omega_{u}, y_{s}$ and $y_{u}$ due to water fluxes must satisfy conservation of mass. As implied above, we ignored density variations due to changes in temperature and expressed the mass of water per square meter of area by the volume of liquid water per square meter of area, so that the units of mass of water per unit area were given in $\mathrm{m}^{3} \mathrm{~m}^{-2}=\mathrm{m}$, which is consistent with water flux units of $\mathrm{m}^{3} \mathrm{~m}^{-2} \mathrm{~s}^{-1}=\mathrm{m} \mathrm{s}^{-1}$.

The derivations of the following equations can be found in Appendix A.3.2.4 in Schymanski (2007). Downwards flux of water into the saturated zone results in its expansion into the unsaturated zone, while an upward flux results in its contraction and an increased unsaturated volume. The change in the thickness of the saturated zone $\left(y_{s}\right)$ was thus expressed as a function of the fluxes in and out of the saturated zone and the saturation of the bottom layer of unsaturated zone $\left(s_{u, \text { nlayers }}\right)$ :

$\frac{\partial y_{s}(t)}{\partial t}=\frac{E_{s s}(t)+Q_{\text {nlayers }}(t)+Q_{s f}(t)}{\varepsilon\left(s_{u, \text { nlayers }}(t)-1\right)}$

where $E_{s s}\left(\mathrm{~m} \mathrm{~s}^{-1}\right)$ is the soil evaporation rate from the saturated zone, $Q_{\text {nlayers }}\left(\mathrm{m} \mathrm{s}^{-1}\right)$ is the flux across the bottom boundary of the unsaturated zone, $Q_{s f}\left(\mathrm{~m} \mathrm{~s}^{-1}\right)$ is outflow across the seepage face and $\varepsilon$ is the soil porosity (here taken as $\left.\varepsilon=\theta_{s}-\theta_{r}, \mathrm{~m}^{3} \mathrm{~m}^{-3}\right)$. The division by $\varepsilon\left(s_{u, \text { nlayers }}(t)-1\right)$ in Eq. 13 reflects the fact that the saturated zone can only expand into the air-filled volume of the unsaturated zone.

The change in soil moisture for the top soil layer was written as:

$\frac{\partial s_{u, 1}(t)}{\partial t}=\frac{-E_{s u}(t)+Q_{1}(t)+Q_{i n f}(t)-Q_{r, 1}(t)}{\varepsilon \omega_{u} \delta_{y u, 1}}$

and for the soil layers between the top and the bottom layer:

$\frac{\partial s_{u, i}(t)}{\partial t}=\frac{-Q_{i-1}(t)+Q_{i}(t)-Q_{r, 1}(t)}{\varepsilon \omega_{u} \delta_{y u, i}}$

To calculate the change in the state variables for a finite time step from $t_{1}$ to $t_{2}$, the above equations were solved at $t_{1}$ and then multiplied by the length of the time step. This gave $y_{s}$ and $s_{u, i}$ at time $t_{2}$ for all layers apart from the bottom layer of the unsaturated zone. The saturation degree in the bottom layer at time $t_{2}\left(s_{u}\right.$,nlayers $\left.\left(t_{2}\right)\right)$ was then calculated by difference from the fluxes into and out of the whole soil domain and the change in water storage. The water storage in each soil layer $i\left(w_{s, i}, \mathrm{~m}\right)$ was written as

$w_{s, i}=\varepsilon \omega_{u} s_{u, i} \delta_{y u, i}$ 
and the sum of fluxes in and out of the soil domain between time $t_{1}$ and $t_{2}$ was written as:

$$
\begin{aligned}
& \Delta w_{c}=\left(t_{2}-t_{1}\right) \\
& \left(Q_{\text {inf }}\left(t_{1}\right)-\sum_{i=1}^{n_{\text {layers }}}\left(Q_{r, i}\left(t_{1}\right)\right)-E_{s s}\left(t_{1}\right)-E_{s u}\left(t_{1}\right)-Q_{s f}\left(t_{1}\right)\right)
\end{aligned}
$$

where $\Delta w_{c}(\mathrm{~m})$ denotes the change in the total water store of the soil domain per unit catchment area. The water store in the bottom soil layer of the unsaturated zone $\left(w_{s, \text { nlayers }}, \mathrm{m}\right)$ at time $t_{2}$ was calculated as

$$
\begin{aligned}
& w_{s, \text { nlayers }}\left(t_{2}\right)=\Delta w_{c}+\sum_{i=1}^{n_{\text {layers }}} w_{s, i}\left(t_{1}\right)+\varepsilon y_{s}\left(t_{1}\right) \\
& -\sum_{i=1}^{n_{\text {layers }}-1} w_{s, i}\left(t_{2}\right)-\varepsilon y_{s}\left(t_{2}\right)
\end{aligned}
$$

and the value of $s_{u, \text { nlayers }}$ at time $t_{2}$ was then obtained from $w_{\text {s,nlayers }}$ :

$$
s_{u, \text { nlayers }}\left(t_{2}\right)=\frac{w_{s, \text { nlayers }}\left(t_{2}\right)}{\varepsilon \omega_{u}\left(t_{2}\right) \delta_{y u, \text { nlayers }}\left(t_{2}\right)}
$$

The maximum length of each time step was restricted so that no state variable in the model could change by more than $10 \%$ in a single time step.

\subsection{Vegetation water balance and root water uptake}

Root water uptake was modelled using an electrical circuit analogy, where radial root resistivity and soil resistivity are in series in each soil layer (Hunt et al., 1991). Water uptake per unit root surface area in a soil layer $\left(J_{r, i}, \mathrm{~m} \mathrm{~s}^{-1}\right)$ was thus written as:

$J_{r, i}=\frac{h_{r, i}-h_{i}}{\Omega_{r}+\Omega_{s, i}}$

where $\Omega_{r}$ is root resistivity to water uptake per unit root surface area (taken as $1.02 \times 10^{8} \mathrm{~s}$ in this study), and $\Omega_{s, i}$ (s) is the resistivity to water flow towards the roots in the soil. The driving force for water uptake by roots is the difference between the forces holding the water in the soil $\left(h_{i}, \mathrm{~m}\right.$ head) and the forces holding the water in the roots $\left(h_{r, i}, \mathrm{~m}\right.$ head). Defining $S_{A r, i}\left(\mathrm{~m}^{2} \mathrm{~m}^{-2}\right)$ as the root surface area per ground area in layer $i$, we can write the root water uptake rate per ground area in layer $i\left(Q_{r, i}, \mathrm{~m} \mathrm{~s}^{-1}\right)$ as:

$Q_{r, i}=S_{A r, i}\left(\frac{h_{r, i}-h_{i}}{\Omega_{r}+\Omega_{s, i}}\right)$

The resistivity to water flow towards the roots in the soil $\left(\Omega_{s, i}, \mathrm{~s}\right)$ was formulated as a function of the unsaturated hydraulic conductivity $\left(K_{\text {unsat }, i}, \mathrm{~m} \mathrm{~s}^{-1}\right)$, root radius $\left(r_{r}, \mathrm{~m}\right)$ and root surface area density in soil layer $i\left(S_{A d r, i}, \mathrm{~m}^{2} \mathrm{~m}^{-3}\right)$ :

$\Omega_{s, i}=\frac{1}{K_{\mathrm{unsat}, i}} \sqrt{\frac{\pi r_{r}}{2 S_{A d r, i}}}$
Equation (22) has the desired properties that $\Omega_{s, i}$ decreases with increasing $K_{\text {unsat }, i}$ and decreasing distance between roots (represented by the second term). A derivation of Eq. (22) is given in Appendix A.3.3.1 in Schymanski (2007).

\subsubsection{Water storage and tissue balance pressure}

In the above, root water uptake was modelled as a function of root and soil properties and the suction head difference between the soil and the inside of the roots. The suction head inside the roots is often considered to be linked to the suction head in leaves, which is caused by adhesive forces and is driven by transpiration. Thus, water transport from the soil to the leaves could occur passively, without the expenditure of energy other than for the maintenance of the plant tissues involved. A model to quantify the forces involved in such a passive process has been developed in Appendix A.3.3.2 in Schymanski (2007) and will only be summarised here. Based on work by Roderick and Canny (2005), who found a correlation between measurements of tissue balance pressure $\left(P_{b}\right.$, the pressure that has to be applied in order to force water out of the tissue) and the tissue water content $\left(M_{q}\right)$, the relationship was written as:

$P_{b}=\left(M_{q x}-M_{q}\right)\left(\frac{c_{1} M_{d}}{\left(M_{d}+M_{q x}\right)^{2}}+\frac{c_{2}}{M_{q x}}\right)$

where $P_{b}$ (bar) is the tissue balance pressure, $M_{q x}$ and $M_{q}$ are the maximum and actual amount of water stored in plant tissues per unit catchment area respectively $\left(\mathrm{kg} \mathrm{m}^{-2}\right), M_{d}$ $\left(\mathrm{kg} \mathrm{m}^{-2}\right)$ is the total mass of dry matter associated with living tissues per unit catchment area, and $c_{1}$ (750 bar) and $c_{2}$ ( 1 bar) are fitted to match the data presented by Roderick and Canny (2005). If the tissue balance pressure is assumed to represent the suction force exerted by the tissue, Eq. (23) implies that the suction force increases as the tissue water content decreases. However, $P_{b}$ can only increase until $M_{q}$ reaches a value of $0.9 M_{q x}$, because any further decrease in water content is assumed to lead to tissue damage (see Appendix A.3.2.2 in Schymanski, 2007).

In order to use the tissue balance pressure in plant organs above ground $\left(P_{b}\right)$ as a driver for passive water uptake by roots in the model, $P_{b}$ was translated into the root suction head $h_{r, i}(\mathrm{~m})$ by taking into account the hydrostatic head between roots and trunks:

$h_{r, i}=c_{P b m} P_{b}-h_{h, i}$

where $h_{h, i}(\mathrm{~m})$ is the hydrostatic head difference between the soil surface and the depth of layer $i$, while $c_{P b m}=10.2 \mathrm{mbar}^{-1}$ is a conversion coefficient to convert from units of $P_{b}$ (bar) to units of $h_{r, i}(\mathrm{~m})$. The height of the canopy was not considered in the calculation of $h_{r, i}$, as the model did not include any information about tree heights.

While it is clear from the above that the value of $M_{q}$ is important for calculating water uptake rates by roots in the 
present model, it was also postulated that $M_{q}$ should not decrease below $90 \%$ of its maximum value, $M_{q x}$. The rate of change in $M_{q}$ was written as a function of root water uptake and transpiration rate:

$$
\frac{\partial M_{q}(t)}{\partial t}=\rho_{w} \sum_{i=1}^{i_{r}} Q_{r, i}(t)-E_{t}(t)
$$

where $\rho_{w}\left(1000 \mathrm{~kg} \mathrm{~m}^{-3}\right)$ is the density of water, $Q_{r, i}\left(\mathrm{~m} \mathrm{~s}^{-1}\right)$ is the water uptake rate by tree roots in soil layer $i, i_{r}$ is the deepest soil layer accessed by roots and $E_{t}\left(\mathrm{~m} \mathrm{~s}^{-1}\right)$ is the transpiration rate. To hold $M_{q}$ above $0.9 M_{q x}$, we prescribed root-induced stomatal closure whenever $E_{t}$ would otherwise exceed root water uptake at $M_{q}=0.9 M_{q x}$. A large tree water storage capacity $\left(M_{q x}\right)$ can act as a buffer for meeting peak foliage water demands that exceed root water uptake rates during the day.

Ideally, water use by trees and grasses should be modelled separately because the grasses that dominate the fluxes during the wet season have a much smaller water storage capacity than trees, which can store water in their sapwood. For the purpose of the present study, however, it was not feasible to distinguish tree water use from grass water use, and hence trees and grasses were treated as one system with a common water storage capacity. The error was not expected to be very large, as the effect of the tissue water storage on root water uptake should be relatively small during the wet season, when soil moisture is high.

The total above-ground volume of sapwood at the study site was estimated to be $0.0032 \mathrm{~m}^{3}$ per $\mathrm{m}^{2}$ catchment area and observed mean values of sapwood density ranged between species from 0.81 to $0.94 \mathrm{~g} \mathrm{~cm}^{-3}$ (Cernusak et al., 2006). In rough terms, this gives an estimated $3.0 \mathrm{~kg}$ of sapwood dry matter per $\mathrm{m}^{2}$ catchment area. To also account for the dry mass in tree leaves with a leaf area index of 0.6 and a specific leaf area of $5.5 \mathrm{~m}^{2} \mathrm{~kg}^{-1}$ (Cernusak et al., 2006), we used $3.1 \mathrm{~kg} \mathrm{~m}^{-2}$ for $M_{d}$ in the model. Taking a typical value for Eucalyptus leaves (Roderick and Canny, 2005), we set $M_{q x}=M_{d}$ in the present model, which also allows the maximum values of $P_{b}$ in Eq. (23).

\subsubsection{Costs and benefits of the root system}

We assumed that there would be a relationship between the vegetation's capacity to extract water from the soil and the amount of carbon that has to be invested in the root system. Unfortunately, such a general relationship was difficult to obtain from the literature, as respiration rates, root hydraulic properties and turnover rates are rarely measured on the same plants, while all of these parameters are highly variable, not only between species, but even within the same root over time (Steudle, 2000).

In the absence of a general empirical relationship between root costs and their water uptake capacity, we used measurements on citrus roots, for which observations of both respi- ration rates and hydraulic properties were available in the literature. Note that there is no evidence suggesting similarity between citrus roots and the roots of the savanna vegetation on the study site, but we hypothesise that the relationship between fine root water uptake capacity and fine root respiration would be roughly similar over a wide range of species.

Huang and Eissenstat (2000) measured radial conductivity in different citrus species and found hydraulic conductivities of 1 to $3 \mu \mathrm{m} \mathrm{s}^{-1} \mathrm{MPa}^{-1}$ per $\mathrm{m}^{2}$ root area in first-order lateral roots ( 0.34 to $0.44 \mathrm{~mm}$ diameter). In second-order lateral roots ( 0.58 to $0.87 \mathrm{~mm}$ diameter), they found values of 0.2 to $0.75 \mu \mathrm{m} \mathrm{s}^{-1} \mathrm{MPa}^{-1} \mathrm{~m}^{-2}$. Using $1 \mu \mathrm{m} \mathrm{s}^{-1} \mathrm{MPa}^{-1} \mathrm{~m}^{-2}$ as a typical value for radial root conductivity per root area and converting to units of hydraulic head, we set the root resistivity to water uptake $\left(\Omega_{r}\right)$ to $1.02 \times 10^{8} \mathrm{~s}$.

Bryla et al. (2001) gave values of root respiration for a single citrus fine root on a dry weight (DW) basis in the order of $10 \mathrm{nmol}(\mathrm{g} \mathrm{DW})^{-1} \mathrm{~s}^{-1}$. The average fine root diameter of the measured roots was $0.6 \mathrm{~mm}$. Eissenstat (1991) gave values for the dry mass to volume relationships of different citrus roots between 0.15 and $0.2 \mathrm{~g} \mathrm{~cm}^{-3}$. Taking $0.17 \mathrm{~g} \mathrm{~cm}^{-3}$ as a typical value, $1 \mathrm{~m}^{3}$ root volume would have a dry weight of $0.17 \times 10^{6} \mathrm{~g}$. Consequently, the respiration rate for $1 \mathrm{~m}^{3}$ of fine roots would be $0.0017 \mathrm{~mol} \mathrm{~s}^{-1}$. Assuming cylindrical roots, we obtained root respiration per unit catchment area $\left(R_{r}, \mathrm{~mol} \mathrm{~m}^{-2} \mathrm{~s}^{-1}\right)$ as a function of root radius $\left(r_{r}, \mathrm{~m}\right)$ and root surface area per unit ground area $\left(S_{A r}, \mathrm{~m}^{2} \mathrm{~m}^{-2}\right)$ :

$R_{r}=c_{R r}\left(\frac{r_{r}}{2} S_{A r}\right)$

where, following the above, $c_{R r}=0.0017 \mathrm{~mol} \mathrm{~s}^{-1} \mathrm{~m}^{-3}$ and $r_{r}=0.3 \times 10^{-3} \mathrm{~m}$. The root surface area per unit ground area $\left(S_{A r}, \mathrm{~m}^{2} \mathrm{~m}^{-2}\right)$ was modelled as the sum of the root surface area densities in all soil layers $\left(S_{A d r, i}, \mathrm{~m}^{2} \mathrm{~m}^{-3}\right)$ multiplied by the volumes of the respective soil layers per unit ground area:

$S_{A r}=\sum_{i=1}^{i_{r}} S_{A d r, i} \delta_{y u, i} \omega_{u}$

\subsection{Root optimisation}

The canopy water demand, determined by the observed transpiration rates, has to be met by root water uptake, so that the optimisation problem for the root system is the minimisation of costs while meeting the water demand by the canopy. The optimisation of the root system was performed on a daily scale and involved two steps. The first step was to determine whether the actual root surface area was more or less than adequate to meet the water demand during the past day. This was performed by recording the minimum value of the tissue water store $\left(M_{q}, \mathrm{~kg} \mathrm{~m}^{-2}\right)$ during the past day $\left(M_{q \mathrm{~min}}\right.$, $\mathrm{kg} \mathrm{m}^{-2}$ ), which was then used to compute a coefficient of change for the root system $\left(k_{r}\right)$ :

$k_{r}=\frac{0.95 M_{q x}-M_{q \min }}{0.05 M_{q x}}$ 
$M_{q \text { min }}$ can range between $0.9 M_{q x}$ and $M_{q x}$. A value of $M_{q \min }=0.9 M_{q x}$ suggests that root water uptake did not meet the canopy water demand, causing stomatal closure to prevent further depletion of $M_{q}$, while $M_{q \min }=M_{q x}$ suggests that canopy water demand did not deplete $M_{q}$ at all. The use of the factors 0.95 and 0.05 in Eq. (28) results in $k_{r}$ ranging between 1 for the first case and -1 for the latter case.

The second step was to determine the relative effectiveness of roots in different soil layers $\left(k_{r e f f, i}\right)$ on the past day. This was performed by dividing the daily water uptake per unit root surface area in each soil layer $\left(J_{r \text { daily, } i}, \mathrm{~m} \mathrm{~d}^{-1}\right)$ by the daily water uptake per unit root surface area in the most effective soil layer.

$k_{r \text { eff }, i}=\frac{0.5 J_{r \text { daily }, i}}{\max \left(J_{\left.r_{\text {daily }, i}\right)}\right.}$

The change in root surface area in each soil layer from day to day was computed as a function of $k_{r}$ and $k_{r \text { eff }, i}$ :

$\Delta S_{A d r, i}=G_{r \max } k_{r \text { eff }, i} k_{r}$

where $G_{r \text { max }}\left(\mathrm{m}^{2}\right.$ per $\left.\mathrm{m}^{3}\right)$ is the maximum daily root growth rate. The value of $G_{r \text { max }}$ determines the maximum fine root turnover rate and thereby the flexibility of the root system to respond to changes in soil moisture or canopy water demand. Based on trial and error, the value of $G_{r \text { max }}$ was set to $0.1 \mathrm{~m}^{2}$ per $\mathrm{m}^{3}$ soil volume. This allowed enough flexibility to satisfy the canopy water demand during soil drying while avoiding excessive day-to-day fluctuations of $S_{A d r, i}$ in response to the short-term variability of soil moisture. The optimisation procedure simulates a dynamic adaptation of the root system to the canopy water demand and the water supply in the soil, based on the memory of the past. It allows for a seasonal variation in the vertical root distribution in response to the seasonality of the vertical soil moisture distribution.

\subsection{Prescribed root profile}

For comparison with the conventional approach to modelling root water uptake, we ran the same model with a prescribed, static root distribution. The static root distribution used was the typical root distribution for humid tropical savannas given by Schenk and Jackson (2002), with a root area index of $43 \mathrm{~m}^{2} \mathrm{~m}^{-2}$ as given for tropical grasslands/savannas by Jackson et al. (1997).

\subsection{Study site}

The site chosen for the present study is the Howard Springs eddy covariance site, which is located in the Northern Territory of Australia, $35 \mathrm{~km}$ South-East of Darwin, in the Howard River catchment $\left(12^{\circ} 29^{\prime} 39.30^{\prime \prime} \mathrm{S}, 131^{\circ} 9^{\prime} 8.58^{\prime \prime} \mathrm{E}\right)$.

The climate is sub-humid on an annual basis $(1750 \mathrm{~mm}$ mean annual rainfall, $2300 \mathrm{~mm}$ mean annual class A pan evaporation), but with a very strong monsoonal seasonality. Approximately $95 \%$ of the $1750 \mathrm{~mm}$ mean annual rainfall is restricted to the wet season (December to March, inclusive), while the dry season (May to September) is characterised by virtually no rainfall and high atmospheric water demand (Hutley et al., 2000). Air temperatures range between roughly 25 and $35^{\circ} \mathrm{C}$ in the wet season and between 15 and $30^{\circ} \mathrm{C}$ in the dry season.

The terrain at the study site is very flat, with slopes $<1^{\circ}$ (Beringer et al., 2003, 2007). The surface of the lowland plains, where the study site is situated, is a late Tertiary depositional surface, with a sediment mantle that seldom reaches more than 30 to $40 \mathrm{~m}$ in depth. On the study site itself, the soil profile has been described as a red kandosol, with sandy loams and sandy clay loams in horizons $\mathrm{A}$ and $\mathrm{B}$ respectively and weathered laterite in the $\mathrm{C}$ horizon, below about $1.2 \mathrm{~m}$ (Kelley, 2002).

The site is situated between the Howard River $(4.5 \mathrm{~km}$ to the West, around $20 \mathrm{~m}$ AHD (Australian Height Datum)), and a smaller river channel, $(0.5 \mathrm{~km}$ to the East, around $30 \mathrm{~m} \mathrm{AHD)}$. The terrain reaches a maximum elevation of roughly $40 \mathrm{~m}$ AHD between these two channels. In terms of the catchment conceptualisation in Fig. 1, we interpreted the catchment as having an average depth of the pedosphere $(Z)$ of $15 \mathrm{~m}$, and an average channel elevation $\left(z_{r}\right)$ of $10 \mathrm{~m}$ from the reference datum, which was set to coincide with the average bedrock elevation, so that $z_{s}=0 \mathrm{~m}$ ).

The vegetation has been classified as a Eucalypt open forest (Specht, 1981), with a mean canopy height of $15 \mathrm{~m}$, where the overstorey has an estimated cover of 30-50\% (Hutley et al., 2000; Schymanski et al., 2007) and is dominated by the evergreen Eucalyptus miniata and Eucalyptus tetrodonta. The dominant tree species contribute to $60-70 \%$ of the total basal area (i.e. the ground area covered by tree trunks) of this forest and are accompanied by some brevi-, semi- and fully deciduous tree species (O'Grady et al., 2000). The overstorey leaf area index (LAI) varies little seasonally, between roughly 0.6 during the dry season and 0.95 during the wet season (Hutley et al., 2000). The understorey on the site is highly dynamic. During the dry season it is composed of small individuals of the tree species, some fully or partly deciduous shrubs and some perennial grasses with a total LAI of around 0.2 , while during the wet season it is dominated by up to $2 \mathrm{~m}$ tall annual $\mathrm{C}_{4}$ grasses of the genus Sarga $\mathrm{sp}$. and reaches LAI values of 1.5 (Beringer et al., 2007).

The root system of the vegetation on the site is mainly limited to the top 4-5 m of soil (Kelley, 2002), with single roots observed at depths of up to $9 \mathrm{~m}$, but not in significant quantities (O'Grady, unpubl. data). For the present model, we assumed a constant rooting depth of $5 \mathrm{~m}$ after Kelley (2002).

\subsection{Measurements}

The data used for this study were the same as described in Schymanski et al. (2007, 2008). In summary, transpiration rates were obtained by subtracting estimated soil evaporation rates from the observed latent heat flux using the eddy 

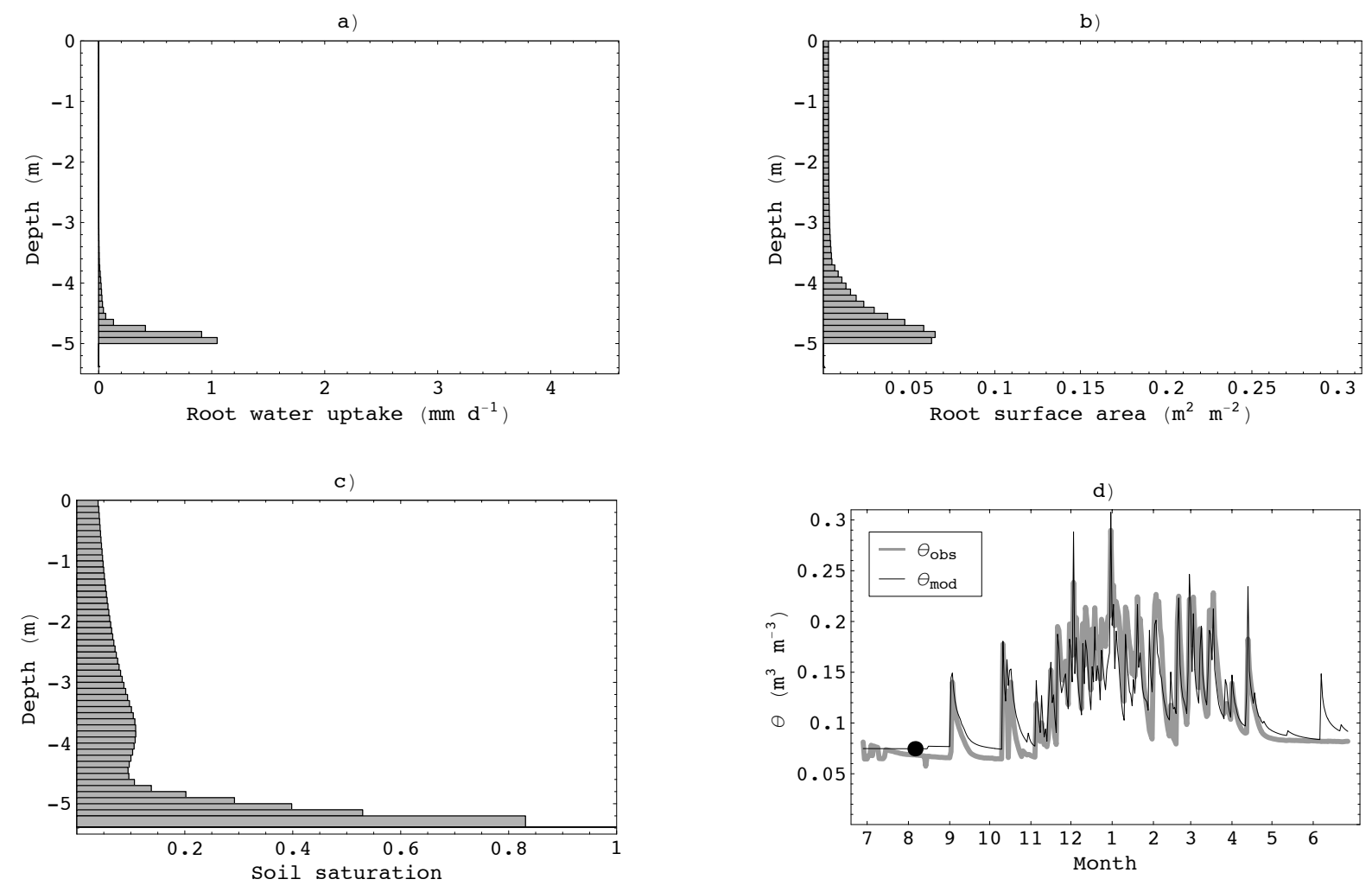

Fig. 3. Simulated below-ground conditions 40 days after model initialisation. Vertical soil profiles show values for each soil layer between the surface and the variable water table. Daily root water uptake $\left(Q_{r, i}\right.$, Plot (a)) and root surface area $\left(S_{A r, i}\right.$, Plot (b)) are highest in the deep layers of the root zone, while soil saturation $\left(s_{u, i}\right.$, Plot $\left.(\mathbf{c})\right)$ is reduced in the layers where the water uptake took place. Plot (d) shows midnight snapshots of the observed and modelled soil moisture in the top soil layer for 12 months, with a round dot indicating the position in time of the other three plots.

covariance technique. Soil evaporation was hereby estimated using the same model as described in Eq. (12), but utilising measured soil moisture. The soil moisture was measured using time domain reflectometry (TDR) probes (CS615 probes, Campbell Scientific, Logan, UT, USA) at $10 \mathrm{~cm}$ depth, and soil temperature was obtained from an averaging soil thermocouple with sensors at 2 and $6 \mathrm{~cm}$ depth.

\section{Results}

\subsection{Dynamically optimised root profile}

As described in Sect. 2.3, the optimality-based model increased or decreased the root surface area at the end of each day based on the daily minimum in the tissue water store $\left(M_{q}\right)$ recorded for that day. If the water store has been drawn down too much, root surface area was increased, otherwise it was decreased. In each individual soil layer, the changes in root surface area were also dependent on this layer's effectiveness in root water uptake relative to all other soil layers.
This optimisation led to the effect that the simulated root distribution seemed to reflect the general direction of water flow. Starting with an equilibrium soil moisture distribution (i.e. no fluxes within the soil domain) and a uniform root distribution in the $5 \mathrm{~m}$ thick root zone, the modelled root system self-optimised to assume a distribution of root surface area $\left(S_{A r, i}\right)$ that was skewed towards the deeper soil after 40 days (Fig. 3). Over the 40 day period, $S_{A r}$ increased from the initial $0.1 \mathrm{~m}^{2} \mathrm{~m}^{-3}$ to $0.7 \mathrm{~m}^{2} \mathrm{~m}^{-3}$ in the lowest root layer. During the dry season, when the root zone can only be recharged from the moister soil layers below, the roots were concentrated at the bottom of the profile. In the wet season, when the soil was wetted from the top, the simulated root distribution shifted towards the top soil layers, where also the majority of water uptake took place (Figs. 4 and 5). A high root surface area also remained in the bottom layer of the root zone, where water supply is lower, but steady. When the distribution of soil moisture was very heterogeneous in the soil profile, the model predicted temporal release of water by roots in the driest soil layers (not shown), but this effect was not evident at the daily time scale. Over $24 \mathrm{~h}$, water uptake 

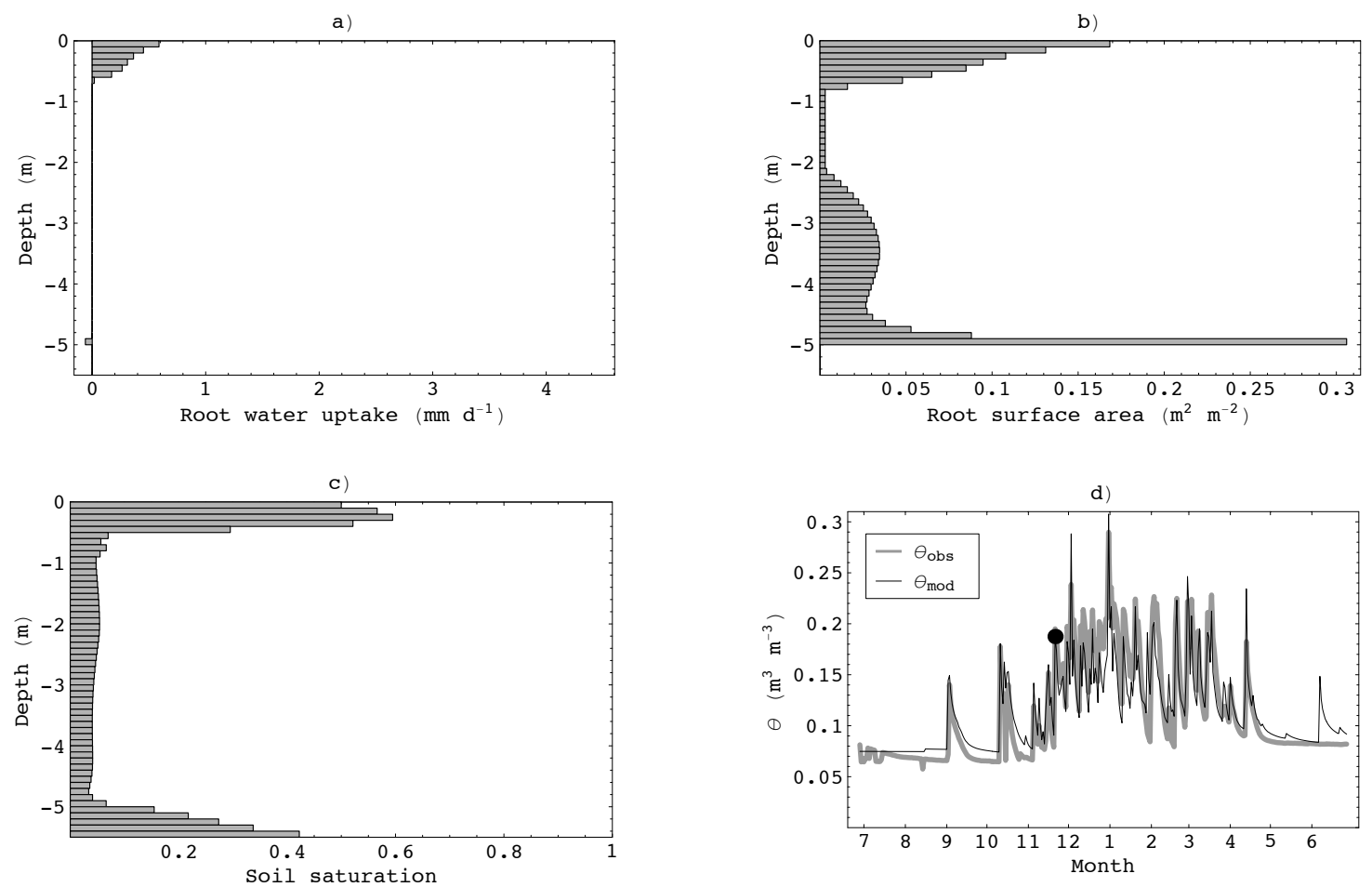

Fig. 4. Simulated below-ground conditions at the onset of the wet season rains (147 days after model initialisation). Vertical soil profiles show values for each soil layer between the surface and the variable water table. The distribution of soil saturation $\left(s_{u, i}\right.$, Plot $\left.(\mathbf{c})\right)$ shows the wetted surface soil, leading to water uptake $\left(Q_{r, i}\right.$, Plot $\left.(\mathbf{a})\right)$ by the top root layers and a slight release of water by the bottom root layer in the early wet season. This caused the root area distribution $\left(S_{A r, i}\right.$, Plot $\left.(\mathbf{b})\right)$ to start shifting towards the upper soil profile, with the bimodal distribution as an intermediate state. Plot (d) shows midnight snapshots of the observed and modelled soil moisture in the top soil layer for 12 months, with a round dot indicating the position in time of the other three plots.

by roots was generally greater than water release in all soil layers, with some exceptions that did not exceed a net water release of $0.06 \mathrm{~mm}$ over $24 \mathrm{~h}$ into a layer $0.1 \mathrm{~m}$ thick. This demonstrates that the dynamic root optimisation, which continuously shifted roots from layers with little daily water uptake to layers with larger daily water uptake (see Sect. 2.3) led to an avoidance of water loss by the root system.

Figure 7 demonstrates that the prescribed plant water storage capacity $\left(M_{q x}\right)$ of $3.1 \mathrm{~kg} \mathrm{~m}^{-2}$ can allow for spikes in transpiration rates during the day and continuing root water uptake during parts of the night, which would not be possible in a model without a significant plant water storage capacity. However, the prescribed $M_{q x}$ of $3.1 \mathrm{~kg} \mathrm{~m}^{-2}$ did not have a large impact on the annual transpiration, which was simulated as $1092 \mathrm{~mm}$, compared with $1089 \mathrm{~mm}$ simulated by the model if a negligible plant water storage capacity was prescribed. The slight discrepancy between the simulated annual transpiration and the observed annual transpiration of $1118 \mathrm{~mm}$ is caused by occasional limitations of transpiration by root water uptake, as shown in Fig. 7. These occurrences are limited to the period between September and November 2004, when the assumed initial soil moisture in the soil pro- file was depleted and prior to its replenishment by the first wet season rain falls. In the second modelled dry season, simulated root water uptake was never limiting for transpiration (Fig. 8a).

Modelled root respiration rates per unit ground area resulting from the dynamically optimised root surface area varied between roughly 0.1 and $0.7 \mu \mathrm{molCO}_{2} \mathrm{~m}^{-2} \mathrm{~s}^{-1}$ (data not shown). This seems reasonable as the minimum observed soil respiration per unit ground area on the site was around $1.5 \mu \mathrm{mol} \mathrm{CO} \mathrm{m}^{-2} \mathrm{~s}^{-1}$ (Chen et al., 2002; Schymanski, 2007), so that the modelled root respiration never exceeded the bulk soil respiration estimated from observations. Note that soil respiration includes the $\mathrm{CO}_{2}$ release by the soil due to the decomposition of organic matter and hence fine root respiration can only be smaller than soil respiration.

Modelled and observed surface soil moisture were very similar both in magnitude as well as dynamics, except for a moderate under-estimation of surface soil moisture by the model at the beginning of the model run (Fig. 6). The mean absolute error (MAE) of the difference between model and observations was $0.0156 \mathrm{~m}^{3} \mathrm{~m}^{-3}$, which is equivalent to about $10 \%$ of the wet season values. Major contributors to 

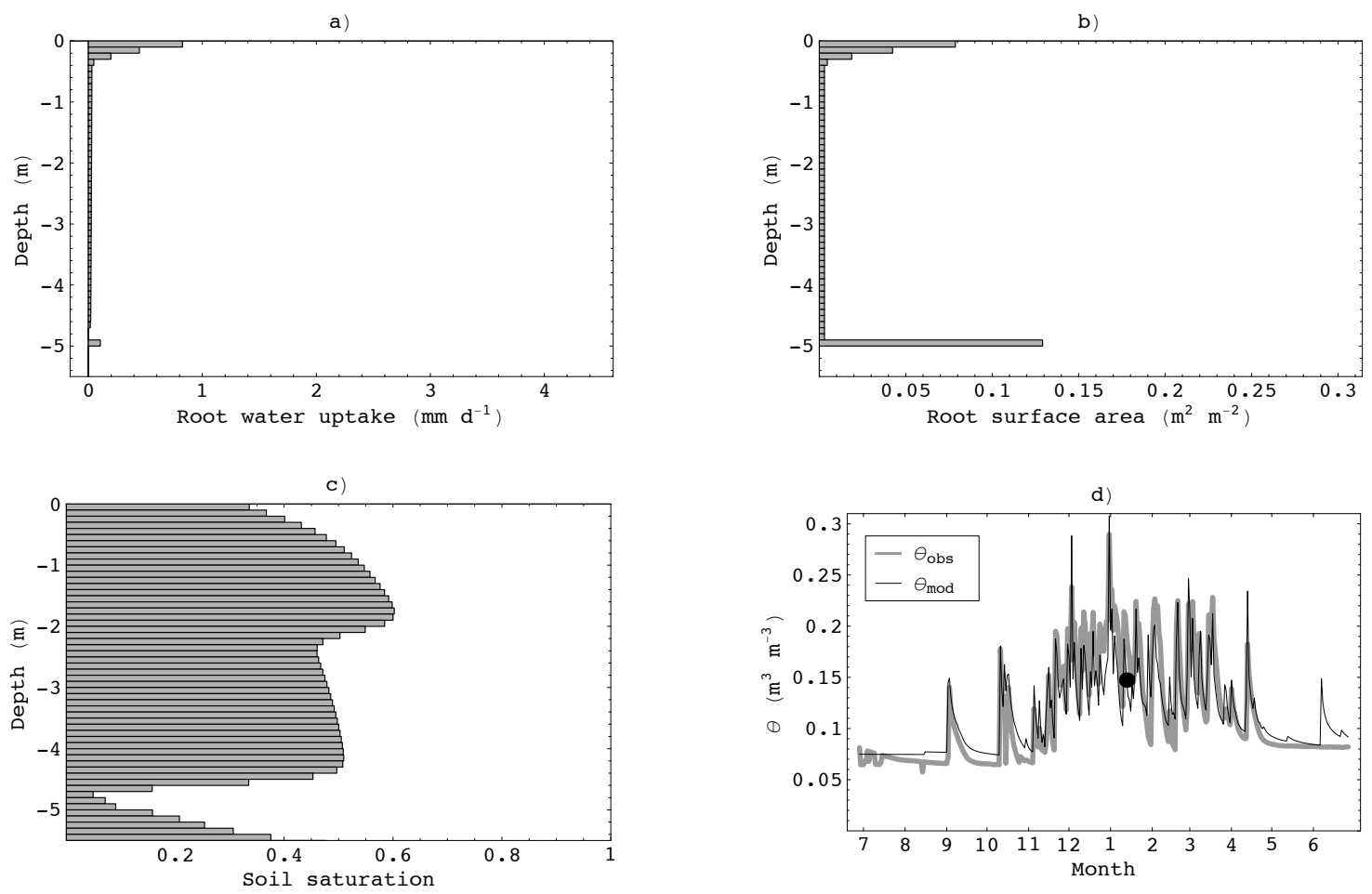

Fig. 5. Simulated below-ground conditions during the mid-wet season (200 days after model initialisation). Vertical soil profiles show values for each soil layer between the surface and the variable water table. The distribution of soil saturation $\left(s_{u, i}\right.$, Plot (c)) shows the propagation of multiple wetting fronts through the soil profile, while the distributions of root surface area $\left(S_{A r, i}\right.$, Plot $\left.(\mathbf{b})\right)$ and root water uptake $\left(Q_{r, i}\right.$, Plot (a)) in the soil profile are concentrated in the top soil with a spike in the lowest layer of the root zone. Plot (d) shows midnight snapshots of the observed and modelled soil moisture in the top soil layer for 12 months, with a round dot indicating the position in time of the other three plots.

this error were an additional spike at the end of the modelled time series, which was not observed in the measurements and a generally faster onset of the simulated surface wetting compared with that observed during rainfalls, which was probably due to the neglected interception.

\subsection{Prescribed, fixed root profile}

The typical root distribution for a savanna found in the literature had an exponential decline of root surface area with depth (Schenk and Jackson, 2002) and a root area index of 43 (Jackson et al., 1997). Prescription of such a fixed root profile led to frequent water release by roots in the model (e.g. Fig. 9a), reaching values of up to $1.3 \mathrm{~mm} \mathrm{~d}^{-1}$ in a single soil layer. A comparison of the observed surface soil moisture time series with the one modelled using the fixed root distribution is given in Fig. 10. The modelled surface soil moisture generally decreased faster than that observed after rainfalls, leading to an under-estimation of surface soil moisture from the start of the wet season on and consequently an increased model error (MAE $=0.02 \mathrm{~m}^{3} \mathrm{~m}^{-3}$ ).

The modelled root water uptake failed to meet the ob- served water demand by the canopy on many occasions (Fig. 8b), leading to a reduced modelled annual transpiration of $1055 \mathrm{~mm}$ compared with the observed $1118 \mathrm{~mm}$. The prescribed root area index of $43 \mathrm{~m}^{2} \mathrm{~m}^{-2}$ led to a constant root respiration rate per unit ground area of $10.9 \mu \mathrm{mol} \mathrm{m}^{-2} \mathrm{~s}^{-1}$, which exceeds the estimated dry season soil respiration rates of $1.5 \mu \mathrm{mol} \mathrm{m}^{-2} \mathrm{~s}^{-1}$ by an order of magnitude.

Assuming a root area index of $10 \mathrm{~m}^{2} \mathrm{~m}^{-2}$, in comparison, led to an improvement in the match between modelled and observed surface soil moisture $\left(\mathrm{MAE}=0.0178 \mathrm{~m}^{3} \mathrm{~m}^{-3}\right)$, but an even higher reduction in modelled annual transpiration (953 mm, Fig. 8c).

\section{Discussion}

The aim of this study was to present and test an optimalitybased model relating root water uptake to carbon costs that is simple enough to be implemented into a coupled ecohydrological model.

The presented root model is easy to couple with an aboveground vegetation model, because the root optimisation is performed dynamically from day to day, without the need for 


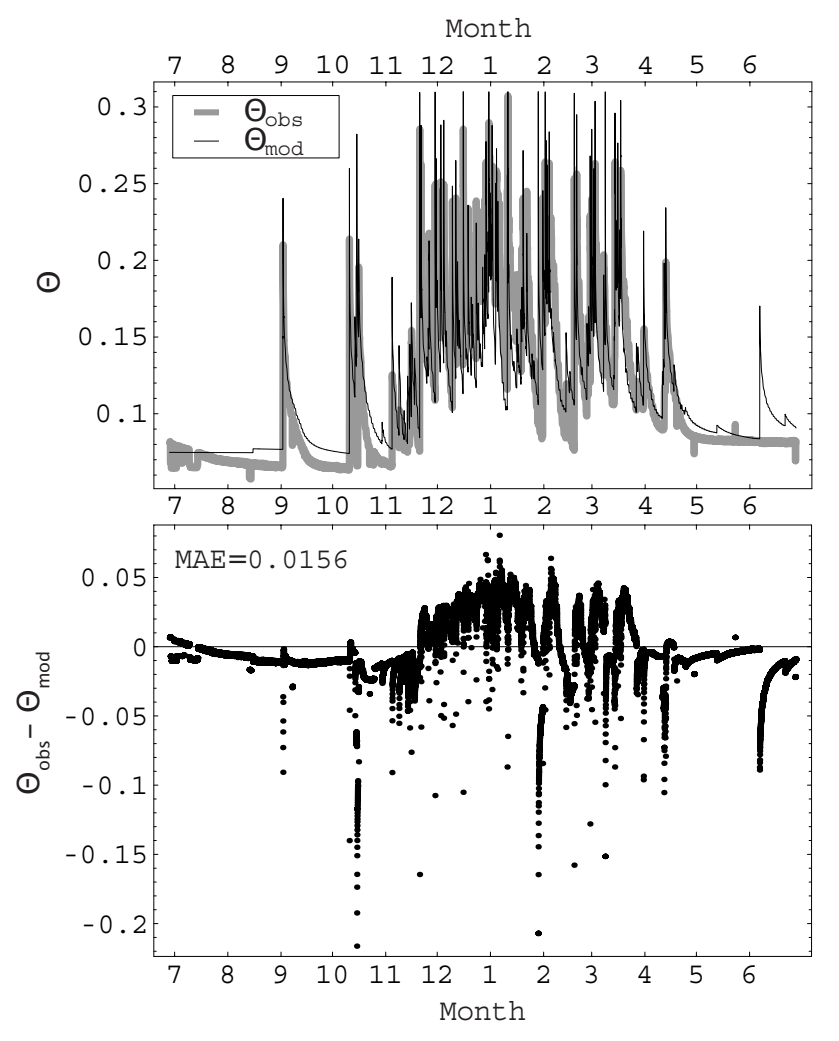

Fig. 6. Observed and modelled half-hourly surface soil moisture $\left(\theta_{\text {obs }}\right.$ and $\theta_{\text {mod }}$ respectively, $\mathrm{m}^{3} \mathrm{~m}^{-3}$ ) (top) and their residuals (bottom) obtained using a dynamically optimised root profile. MAE denotes the mean absolute error of the model.

iterations. The optimality-based model also led to a reasonable reproduction of observed surface soil moisture dynamics and vegetation water use without the need for prescribing a root distribution function or any parameter tuning. In addition, the root respiration rates resulting from the dynamically optimised root distribution never exceeded the soil respiration rates estimated from observations.

In contrast, running the same model with a fixed root distribution, obtained from the literature as a typical one for tropical savannas, led to an under-estimation of vegetation water use and an over-estimation of dry season root respiration by an order of magnitude. We found that arbitrary tuning of the root area index could reduce the over-estimation of root respiration, but would lead to a greater under-estimation of vegetation water use.

Note that the observed transpiration rates were used to prescribe the canopy water demand, and the simulated water use could only deviate from the observed when the root system was less than adequate to satisfy this demand. Hence, simulated water use could only be less than the observed, but should not deviate too much if the root water uptake model was realistic. At the same time, the observed soil respiration should always exceed the simulated root respiration, as soil a)

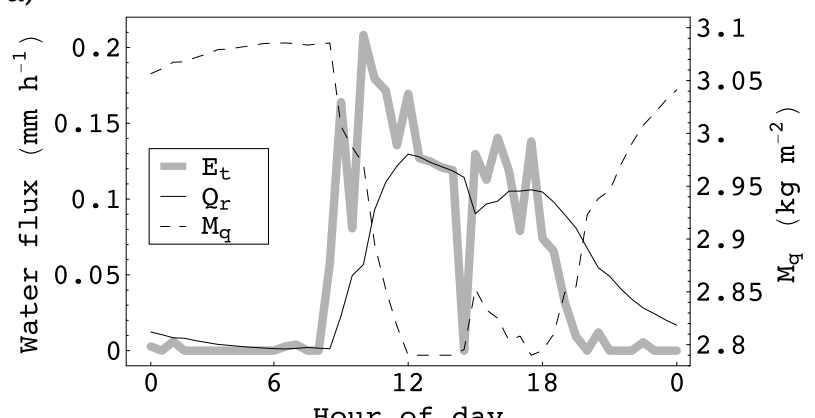

b)

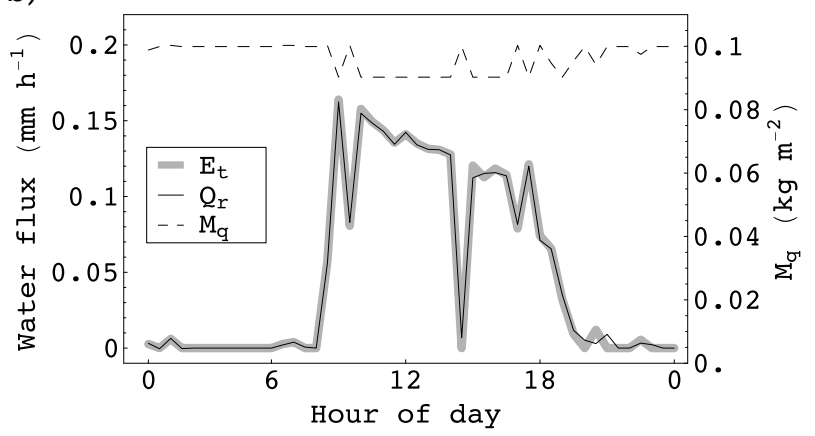

Fig. 7. Comparison of the diurnal dynamics of simulated transpiration $\left(E_{t}\right)$, total root water uptake $\left(Q_{r}\right)$ and plant water storage per unit catchment area $\left(M_{q}\right)$ for two different values of $M_{q x}$. (a) Optimising root distribution, with a water storage capacity $\left(M_{q x}\right)$ of $3.1 \mathrm{~kg} \mathrm{~m}^{-2}$; (b) optimising root distribution, with a water storage capacity $\left(M_{q x}\right)$ of $0.1 \mathrm{~kg} \mathrm{~m}^{-2}$. Data shown for Day 100 of each model run (6 October 2004).

respiration is the sum of root respiration and microbial respiration due to the decomposition of soil carbon. Hence, both the observed water use and the observed soil respiration represent two constraints for a realistic root water uptake model.

Based on these results, the model with a fixed root distribution has to be rejected in favour of the optimality-based model for modelling root water uptake and its associated carbon costs in the given savanna. It may appear trivial that a more complex model (dynamic root distribution) performs better than a simpler model (fixed root distribution) and the question arises whether the better performance of the optimality-based model is due to the optimisation or solely due to its larger complexity compared with the empirical model. The fact is that fine root dynamics can rarely be parameterised empirically, as appropriate observations are not available for most sites. The optimality-based model hence constitutes a major advance in the modelling of dynamic root systems, as it allows parameterising unobserved root system properties without the need for parameter tuning.

One of the reviewers of this paper suggested that the fine root dynamics simulated by the optimality-based model seem unrealistically high. However, recall that the study site has 
a)

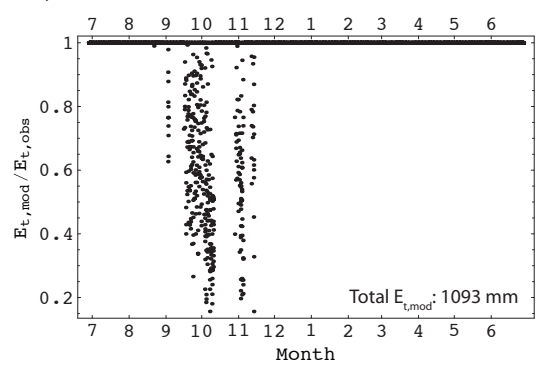

b)

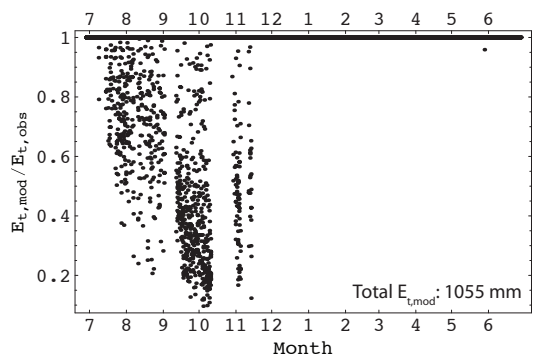

c)

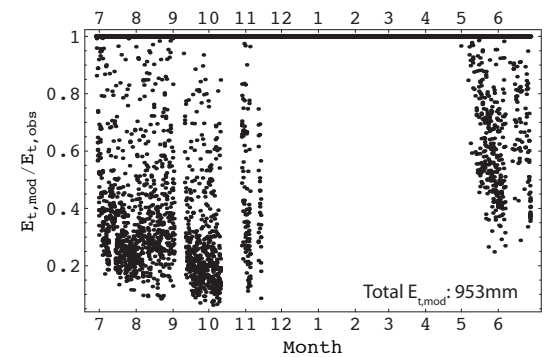

Fig. 8. Comparison of modelled ( $\left.E_{t, \text { mod }}\right)$ and observed ( $\left.E_{t, \text { obs }}\right)$ transpiration rates. (a) Dynamically optimised root profile. (b) Prescribed, static root profile with root area index of 43. (c) Prescribed, static root profile with root area index of 10.

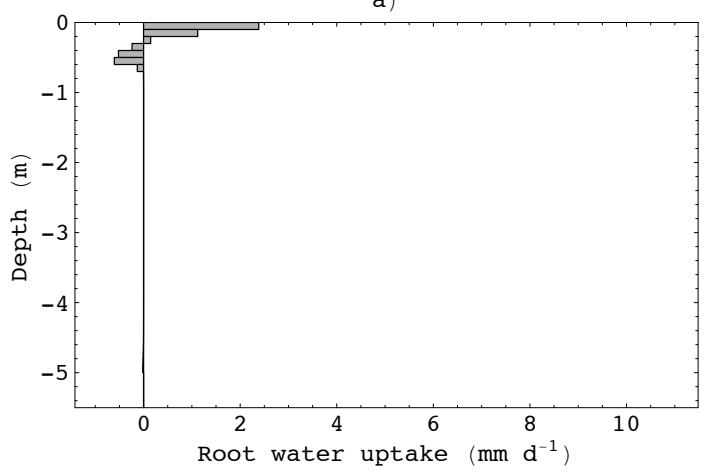

C)

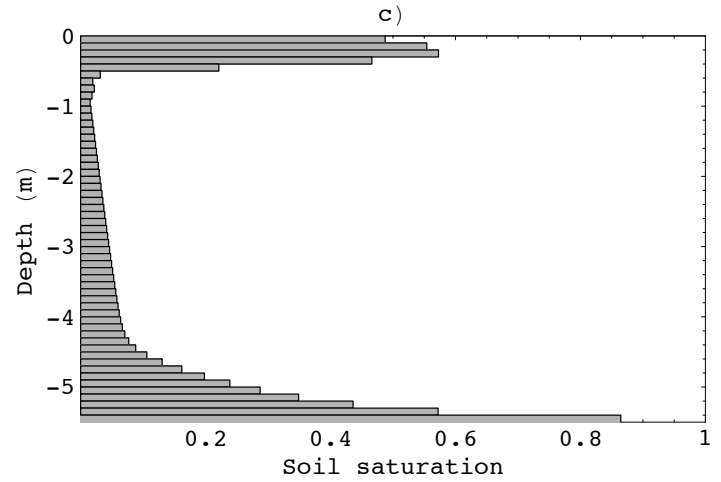

b)

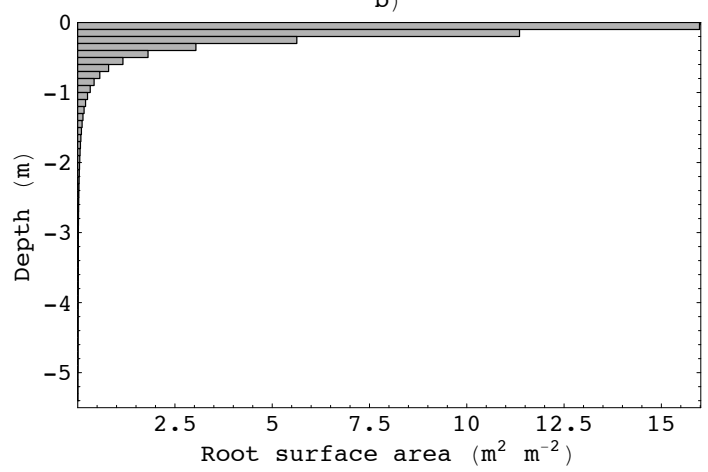

d)

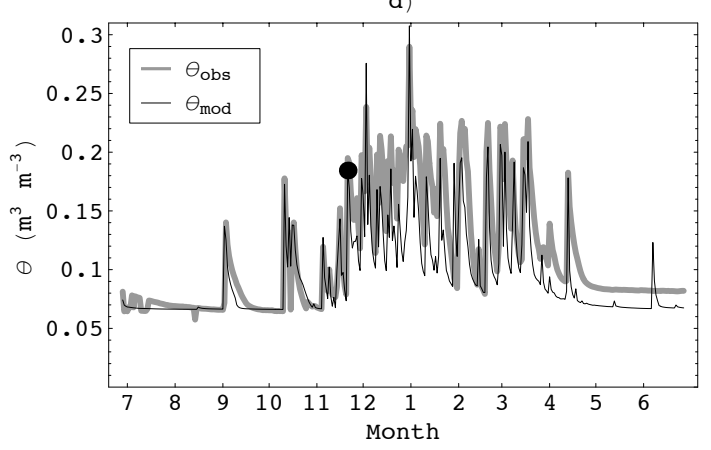

Fig. 9. Simulated below-ground conditions during the early wet season (147 days after model initialisation) simulated using a fixed root distribution. Vertical soil profiles show values for each soil layer between the surface and the variable water table. Note the substantial net water release by roots in certain soil layers on that day in Plot (a) in relation to the fixed root distribution in Plot (b) and the midnight snapshot of the soil moisture distribution in Plot (c). Plot (d) shows midnight snapshots of the observed (grey line) and modelled (black line) soil moisture in the top soil layer for 12 months, with a round dot indicating the position in time of the other three plots. 


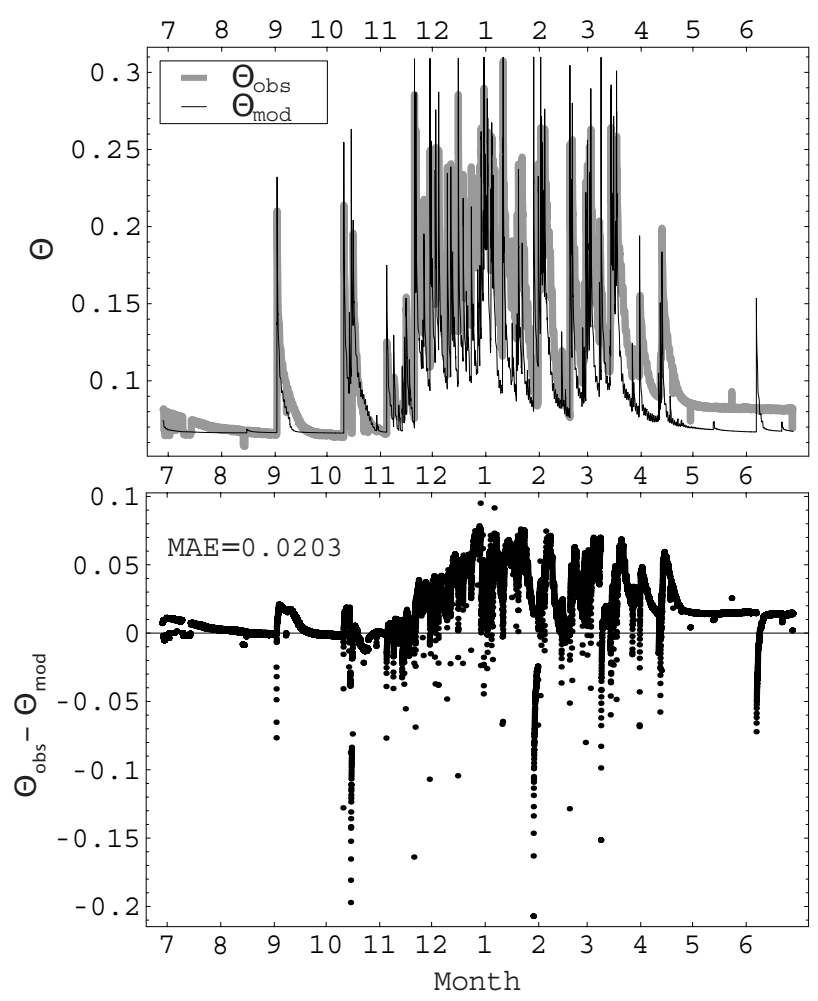

Fig. 10. Observed and modelled half-hourly surface soil moisture $\left(\theta_{\text {obs }}\right.$ and $\theta_{\text {mod }}$ respectively, $\mathrm{m}^{3} \mathrm{~m}^{-3}$ ) (top) and their residuals (bottom) obtained using a fixed root distribution. MAE denotes the mean absolute error of the model.

already been shown to have very dynamic roots (Chen et al., 2002, 2004). The maximum possible fine root increment in the model is determined by the parameter $G_{\mathrm{rmax}}$ in Eq. 30 , which was set to $0.1 \mathrm{~m}^{2} \mathrm{~m}^{-3} \mathrm{~d}^{-1}$. In comparison, Eissenstat (1991) reported fine root growth rates of 0.07$0.15 \mathrm{~cm} \mathrm{~cm}^{-3} \mathrm{wk}^{-1}$ for citrus fine roots with a specific root length of $2 \mathrm{~cm} \mathrm{mg}^{-1}$, as in our manuscript. This would translate to growth rates of $0.19-0.4 \mathrm{~m}^{2} \mathrm{~m}^{-3} \mathrm{~d}^{-1}$, which is more than twice the maximum value prescribed in the model. Eissenstat's values are given for roots growing into fresh soil and represent the behaviour after disturbance, not necessarily the response to natural variability in soil moisture. However, the values prove that roots have the capability to grow very fast, even faster than permitted in our model. The more important question is "under what conditions would plants have an advantage by rapidly adjusting their root distribution in the soil profile?". Our results suggest that a savanna with a highly seasonal soil moisture in the top soil represents such conditions. A recently published paper presents observations of fine root growth under natural conditions in the same vegetation type as the one at our study site (Janos et al., 2008). This paper shows an increase in fine root length in the top $1 \mathrm{~m}$ of soil from 10 to $120 \mathrm{~m} \mathrm{~m}^{-2}$ in 3 weeks, which is equivalent to an average increase in root surface area by $0.01 \mathrm{~m}^{2} \mathrm{~m}^{-3} \mathrm{~d}^{-1}$ if the dominant fine root radius is assumed to be $0.3 \mathrm{~mm}$. In comparison, the maximum fine root growth rate in our model occurred at the beginning of the simulation, when the root surface area increased from 0.1 to $0.7 \mathrm{~m}^{2} \mathrm{~m}^{-3}$ in 40 days at the bottom of the root profile. This is equivalent to an average increase in root surface area by $0.015 \mathrm{~m}^{2} \mathrm{~m}^{-3} \mathrm{~d}^{-1}$. We conclude that Eissenstat's observations confirm that the maximum growth rate theoretically permitted in our model is realistic, while the observations by Janos et al. confirm that the maximum growth rate simulated by our model at the study site is realistic, too.

\subsection{Effect of plant water storage}

Besides avoiding the need for prescribing the abundance and distribution of roots in the soil profile, the model presented here has another innovative feature compared with conventional root water uptake models. Existing models assume that when stomata close, there is no movement of water through the plant system resulting in the abrupt shut-down of root water uptake. Recently, Amenu and Kumar (2007) formulated a root water uptake model that enables the simulation of simultaneous efflux of water from the plant to the soil in layers of dry soil and root water uptake in layers of wet soil at night, when stomata are assumed to be closed. However, observations of prolonged sap flow after the shut-down of canopy transpiration (e.g. Silberstein et al., 2001; Unsworth et al., 2004) and the finding that tree water storage can be important for tree water use suggest that there can be significant net water uptake at night when the plant water store is being filled up (e.g. Goldstein et al., 1998; Meinzer et al., 2003; Zweifel and Häsler, 2001; Zweifel et al., 2001).

The present study explicitly accounts for the water storage capacity of living plant tissues (Roderick and Canny, 2005) and formulates the suction force exerted by the roots as a function of the amount of water stored in the plants. This results in net water uptake during part of the night (Fig. 7), and opens the way for investigating the costs and benefits of water storage tissues. Although the effect of the water store on the site investigated in the current study was relatively small, it is likely to become more important in catchments dominated by large trees (e.g. Meinzer et al., 2004b; Phillips et al., 2003; Unsworth et al., 2004; Waring and Running, 1978). To our knowledge, the presented model is the first one to allow consideration of such effects in hydrology.

\subsection{Hydraulic redistribution}

The present model also allows simulation of processes such as the uptake of water by roots in wet soil and simultaneous release of water by roots in dry soil layers ("hydraulic redistribution"). Hydraulic redistribution (HR) has been widely observed and could be seen as a passive process, which depends on the soil suction head and the root distribution within the soil column (Schulze et al., 1998; Burgess et al., 1998, 2001; Meinzer et al., 2004a; Hultine et al., 2004; Espeleta 
et al., 2004; Brooks et al., 2002). Species not showing HR are often those that shed roots in dry soil patches and thus avoid the loss of water from roots (Espeleta et al., 2004). HR could improve the uptake of nutrients from the surface soil, which would otherwise be inhibited by dryness (Burgess et al., 2001). On the other hand, HR could be an undesired "leak in the system", a view which is supported by the observation that root resistance to water release seems to be generally higher than root resistance to water uptake (Hunt et al., 1991). Although root resistance was assumed to be the same for water movement in both directions in the present study, the predicted water release by roots, when it occurred, was very small and hardly apparent at the daily scale if the root distribution was dynamically optimised. This is in line with field observations elsewhere, which showed that tree roots take up more water from shallow soil than they exude via hydraulic lift (Ludwig et al., 2004). In contrast, if the model was run with a fixed, prescribed root distribution, substantial water release by roots was predicted even at the daily scale, when soil layers with a high root abundance were relatively dry. Dawson (1993) documented the uptake of water by shallow-rooting plant species, that has previously been released near the surface by deep-rooted species. As the present study does not distinguish between tree and grass water use on the site, we could not investigate such behaviour, but the observation that the water released by shallow roots during the night is subsequently taken up during the day does not preclude the possibility that the roots releasing the water belong to different species than the roots taking it up later.

One could conclude that the model run based on root optimisation represents species whose roots avoid dry soils and hence do not show HR, while the model run with a fixed root distribution represents species whose fine roots survive even in dry soil and express pronounced HR. The latter corresponds to previous approaches to modelling HR (e.g. Amenu and Kumar, 2007; Personne et al., 2003), while modelling drought-avoiding roots in a hydrological model has not been done before to our knowledge. The better reproduction of observations by the optimisation-based model suggests that drought-avoiding roots dominate in the investigated savanna, but it does not allow conclusions about the generality of such a strategy. In fact, if root decay and construction were associated with an additional cost in the model, it might turn out to be more beneficial to have a less dynamic root distribution, leading to more frequent root water release. In addition, if the uptake of nutrients was considered as another objective function of fine roots (beside water uptake), it could turn out to be beneficial for the plants to increase the release of water into shallow, dry but well aerated soil layers to increase nutrient availability.

\subsection{Caveats and need for further research}

Although the results presented here appear very promising for the use of the optimality-based model, we wish to point out that the roots were only optimised for the uptake of water. The optimal root distributions may be different if nutrient uptake was made part of the objective function for the optimisation. In addition, variability in root resistivity to water uptake was neglected and the parameterisation of the root costs was very simplistic and based on observations in citrus roots only, although it is known that roots can be very versatile. For instance in Lotus japonicus, radial root hydraulic conductivity has been shown to vary 6 -fold between $8.0 \times 10^{-9} \mathrm{~m} \mathrm{~s}^{-1} \mathrm{MPa}^{-1}$ and $4.7 \times 10^{-8} \mathrm{~m} \mathrm{~s}^{-1} \mathrm{MPa}^{-1}$ on a diurnal basis, due to its control by aquaporins (Henzler et al., 1999). Aquaporins can be thought of as another degree of freedom available to plants for the regulation of their water uptake. For example, they could open when tissue "suction" would lead to water uptake (during the day) and close to reduce the reverse effect at night. Alternatively, they could open in soil patches with high concentrations of particular nutrients and close in nutrient-poor patches, to use the transpiration stream for the selective uptake of nutrients. Perhaps, they could even discriminate salty water against fresher water in salinity-affected soils. However, despite their functional similarity to "Maxwell's demon" (Maxwell, 1871), which was a theoretical construct designed to highlight ways to violate the second law of thermodynamics, aquaporin regulation requires energy expenditure by plant cells, but quantitative data on these costs are not yet available. More research will be needed to understand all of the plants' degrees of freedom related to water uptake and the associated costs.

Given our limited understanding of the below-ground processes related to nutrient and water uptake, the question remains whether application of optimality assumptions or empirical parameterisation of the root system, based on incomplete observations, leads to less uncertainty in models. In vegetation with a highly dynamic root system, as the one investigated in this study, the optimality assumption clearly led to a better representation of root water uptake, respiration rates and surface soil moisture dynamics than prescribed root distributions. On the other hand, Jackson et al. (1997) found that many studies reported little seasonal variations in root biomass, with the exception of savannas. This is not surprising, as the dynamically changing root distribution should only be beneficial where water availability shifts seasonally between different soil depths. If water availability does not vary much or if there is no accessible water in deeper soil layers during the dry season, shifts in the root distribution would not be expected. Our finding that a static root distribution would not allow adequate water uptake to meet the observed canopy demand in the water-limited savanna is also consistent with the findings by Teuling et al. (2006), who found that land surface schemes with a static root distribution are likely to under-estimate root water uptake in water-limited conditions.

Where the root system can be assumed to be reasonably static, fixed parameterisation based on empirical observations can avoid the uncertainty related to the correct param- 
eterisation of the objective functions and associated costs and benefits inherent in the optimality approach. However, the assumption of a static root system is clearly not reasonable for predictions of responses to long-term environmental change (Norby and Jackson, 2000), where, in our opinion, optimality approaches should be preferred over empirical parameterisations.

\section{Conclusions}

Optimality assumptions reduce the need for empirical model parameterisation, which is particularly important for modelling the adaptation of vegetation to environmental change. The present study introduced a model of root water uptake that simulates a dynamically optimising fine root surface area in the soil profile with the objective to meet the canopy water demand while minimising carbon expenditure for fine root maintenance. The simulation results obtained for a tropical savanna are consistent with observations in terms of total water use, surface soil moisture dynamics and soil respiration rates. Given that the results obtained using the dynamically optimising root surface area reproduced available observations even better than results based on an empirically prescribed root distribution, we conclude that the presented model is a useful tool to parameterise the costs and benefits of root water uptake, and allows consideration of belowground adaptation of vegetation to its environment. The model's independence from prescribed root distributions and its low computational demand could make it a powerful tool in conjunction with optimality-based above-ground models to simulate the effects of long-term environmental change on vegetation and the water balance.

Acknowledgements. We thank Nigel Tapper for his support in the data acquisition, Erik Veneklas and Sandra Berry for providing useful literature references, Yoshi Yokoo, Neil Viney, Haksu Lee, Majid Hassanizadeh and Richard Silberstein for helpful advice on various modelling issues and Emma Schymanski for critical review of the manuscript. Thanks also to Praveen Kumar and Thomas Wutzler for helpful comments on the manuscript. The research was funded by the Department for Education, Science and Training, Canberra, and the Cooperative Research Centre for Greenhouse Accounting.

Edited by: S. Manfreda

\section{References}

Amenu, G. G. and Kumar, P.: A model for hydraulic redistribution, Hydrology and Earth System Sciences Discussions, 4, 37193769, 2007.

Beringer, J., Hutley, L. B., Tapper, N. J., Coutts, A., Kerley, A., and O'Grady, A. P.: Fire impacts on surface heat, moisture and carbon fluxes from a tropical savanna in northern Australia, Int. J. Wildland Fire, 12, 333-340, 2003.
Beringer, J., Hutley, L. B., Tapper, N. J., and Cernusak, L. A. Savanna fires and their impact on net ecosystem productivity in North Australia, Global Change Biol., 13, 990-1004, doi:10.1111/j.1365-2486.2007.01334.x, 2007.

Brooks, J. R., Meinzer, F. C., Coulombe, R., and Gregg, J.: Hydraulic redistribution of soil water during summer drought in two contrasting Pacific Northwest coniferous forests, Tree Physiol., 22, 1107-1117, 2002.

Bryla, D. R., Bouma, T. J., Hartmond, U., and Eissenstat, D. M.: Influence of temperature and soil drying on respiration of individual roots in citrus: integrating greenhouse observations into a predictive model for the field, Plant Cell Environ., 24, 781-790, 2001.

Burgess, S. S. O., Adams, M. A., Turner, N. C., and Ong, C. K.: The redistribution of soil water by tree root systems, Oecologia, 115, 306-311, 1998.

Burgess, S. S. O., Adams, M. A., Turner, N. C., White, D. A., and Ong, C. K.: Tree roots: conduits for deep recharge of soil water, Oecologia, 126, 158-165, 2001

Cernusak, L., Hutley, L. B., Beringer, J., and Tapper, N. J.: Stem and leaf gas exchange and their responses to fire in a North Australian tropical savanna, Plant Cell Environ., 29, 632-646, 2006.

Chen, X. Y., Eamus, D., and Hutley, L. B.: Seasonal patterns of soil carbon dioxide efflux from a wet-dry tropical savanna of northern Australia, Aust. J. Bot., 50, 43-51, 2002.

Chen, X. Y., Eamus, D., and Hutley, L. B.: Seasonal patterns of fineroot productivity and turnover in a tropical savanna of northern Australia, J. Trop. Ecol., 20, 221-224, 2004.

Collins, D. B. G. and Bras, R. L.: Plant rooting strategies in water-limited ecosystems, Water Resour. Res., 43, W06407, doi: 10.1029/2006WR005541, 2007.

Cowan, I. R. and Farquhar, G. D.: Stomatal Function in Relation to Leaf Metabolism and Environment, in: Integration of activity in the higher plant, edited by: Jennings, D. H., pp. 471-505, Cambridge University Press, Cambridge, 1977.

Dawson, T. E.: Hydraulic Lift and Water-Use by Plants - Implications for Water-Balance, Performance and Plant-Plant Interactions, Oecologia, 95, 565-574, 1993.

Eissenstat, D. M.: On the Relationship between Specific Root Length and the Rate of Root Proliferation - a Field-Study Using Citrus Rootstocks, New Phytologist, 118, 63-68, 1991.

Espeleta, J. F., West, J. B., and Donovan, L. A.: Species-specific patterns of hydraulic lift in co-occurring adult trees and grasses in a sandhill community, Oecologia, 138, 341-349, 2004.

Feddes, R. A., Hoff, H., Bruen, M., Dawson, T., de Rosnay, P., Dirmeyer, O., Jackson, R. B., Kabat, P., Kleidon, A., Lilly, A., and Pitman, A. J.: Modeling root water uptake in hydrological and climate models, B. Am. Meteorol. Soc., 82, 2797-2809, 2001.

Giard, D. and Bazile, E.: Implementation of a New Assimilation Scheme for Soil and Surface Variables in a Global NWP Model, Mon. Weather Rev., 128, 997-1015, 2000.

Goldstein, G., Andrade, J. L., Meinzer, F. C., Holbrook, N. M., Cavelier, J., Jackson, P., and Celis, A.: Stem water storage and diurnal patterns of water use in tropical forest canopy trees, Plant Cell Environ., 21, 397-406, 1998.

Henzler, T., Waterhouse, R. N., Smyth, A. J., Carvajal, M., Cooke, D. T., Schäffner, A. R., Steudle, E., and Clarkson, D. T.: Diurnal variations in hydraulic conductivity and root pressure can be cor- 
related with the expression of putative aquaporins in the roots of Lotus japonicus, Planta, 210, 50-60, 1999.

Huang, B. R. and Eissenstat, D. M.: Linking hydraulic conductivity to anatomy in plants that vary in specific root length, J. Am. Soc. Hortic. Sci., 125, 260-264, 2000.

Hultine, K. R., Scott, R. L., Cable, W. L., Goodrich, D. C., and Williams, D. G.: Hydraulic redistribution by a dominant, warmdesert phreatophyte: seasonal patterns and response to precipitation pulses, Funct. Ecol., 18, 530-538, 2004.

Hunt, E. R., Running, S. W., and Federer, C. A.: Extrapolating Plant Water-Flow Resistances and Capacitances to Regional Scales, Agric. Forest Meteorol., 54, 169-195, 1991.

Hutley, L. B., O'Grady, A. P., and Eamus, D.: Evapotranspiration from eucalypt open-forest savanna of northern Australia, Funct. Ecol., 14, 183-194, 2000.

Jackson, R. B., Mooney, H. A., and Schulze, E. D.: A global budget for fine root biomass, surface area, and nutrient contents, Proceedings of the National Academy of Sciences of the United States of America, 94, 7362-7366, 1997.

Jackson, R. B., Schenk, H. J., Jobbagy, E. G., Canadell, J., Colello, G. D., Dickinson, R. E., Field, C. B., Friedlingstein, P., Heimann, M., Hibbard, K., Kicklighter, D. W., Kleidon, A., Neilson, R. P., Parton, W. J., Sala, O. E., and Sykes, M. T.: Belowground consequences of vegetation change and their treatment in models, Ecol. Appl., 10, 470-483, 2000.

Janos, D. P., Scott, J., and Bowman, D. M. J. S.: Temporal and spatial variation of fine roots in a northern Australian Eucalyptus tetrodonta savanna, Journal of Tropical Ecology, 24, 177-188, doi:10.1017/S0266467408004860, 2008.

Kelley, G.: Tree water use and soil water dynamics in savannas of northern Australia, Ph.D. thesis, Northern Territory University, Darwin, Australia, 2002.

Kleidon, A. and Heimann, M.: Simulating root carbon-water storage with a coupled carbon - Water cycle root model, Phys. Chem. Earth, 21, 499-502, 1996.

Kleidon, A. and Heimann, M.: A method of determining rooting depth from a terrestrial biosphere model and its impacts on the global water and carbon cycle, Global Change Biol., 4, 275-286, 1998.

Laio, F., D’Odorico, P., and Ridolfi, L.: An analytical model to relate the vertical root distribution to climate and soil properties, Geophysical Research Letters, 33, doi:ARTNL18401, 2006.

Lee, T. J. and Pielke, R. A.: Estimating the Soil Surface SpecificHumidity, J. Appl. Meteorol., 31, 480-484, 1992.

Ludwig, F., Dawson, T. E., Prins, H. H. T., Berendse, F., and de Kroon, H.: Below-ground competition between trees and grasses may overwhelm the facilitative effects of hydraulic lift, Ecol. Lett., 7, 623-631, 2004.

Maxwell, J. C.: Theory of heat, Longman's, Green and Co., London, 1871.

Meinzer, F. C., Goldstein, G., and Andrade, J. L.: Regulation of water flux through tropical forest canopy trees: Do universal rules apply?, Tree Physiol., 21, 19-26, 2001.

Meinzer, F. C., James, S. A., Goldstein, G., and Woodruff, D.: Whole-tree water transport scales with sapwood capacitance in tropical forest canopy trees, Plant Cell Environ., 26, 1147-1155, 2003.

Meinzer, F. C., Brooks, J. R., Bucci, S., Goldstein, G., Scholz, F. G., and Warren, J. M.: Converging patterns of uptake and hy- draulic redistribution of soil water in contrasting woody vegetation types, Tree Physiol., 24, 919-928, 2004a.

Meinzer, F. C., James, S. A., and Goldstein, G.: Dynamics of transpiration, sap flow and use of stored water in tropical forest canopy trees, Tree Physiol., 24, 901-909, 2004b.

Norby, R. J. and Jackson, R. B.: Root dynamics and global change: seeking an ecosystem perspective, New Phytologist, 147, 3-12, 2000.

O'Grady, A. P., Chen, X., Eamus, D., and Hutley, L. B.: Composition, leaf area index and standing biomass of eucalypt open forests near Darwin in the Northern Territory, Australia, Aust. J. Bot., 48, 629-638, 2000.

Personne, E., Perrier, A., and Tuzet, A.: Simulating water uptake in the root zone with a microscopic-scale model of root extraction, Agronomie, 23, 153-168, 2003.

Phillips, N. G., Ryan, M. G., Bond, B. J., McDowell, N. G., Hinckley, T. M., and Cermak, J.: Reliance on stored water increases with tree size in three species in the Pacific Northwest, Tree Physiol., 23, 237-245, 2003.

Radcliffe, D. E. and Rasmussen, T. C.: Soil Water Movement, in: Soil Physics Companion, edited by: Warrick, A. W., pp. 85-126, CRC Press, Boca Raton, 2002.

Raupach, M. R.: Dynamics and Optimality in Coupled Terrestrial Energy, Water, Carbon and Nutrient Cycles, in: Predictions in Ungauged Basins: International Perspectives on State of the Art and Pathways Forward, edited by: Franks, S. W., Sivapalan, M., Takeuchi, K., and Tachikawa, Y., vol. 301 of IAHS Publication, chap. 19, pp. 223-238, IAHS Press, Wallingford, 2005.

Reggiani, P., Sivapalan, M., and Hassanizadeh, S. M.: Conservation equations governing hillslope responses: Exploring the physical basis of water balance, Water Resour. Res., 36, 1845-1863, 2000.

Roderick, M. L. and Canny, M. J.: A mechanical interpretation of pressure chamber measurements - what does the strength of the squeeze tell us?, Plant Physiol. Bioch., 43, 323-336, 2005.

Schenk, H. J.: Vertical Vegetation Structure Below Ground: Scaling from Root to Globe, Progress in Botany, 66, 341-373, 2005.

Schenk, H. J. and Jackson, R. B.: The global biogeography of roots, Ecol. Monogr., 72, 311-328, 2002.

Schulze, E. D., Caldwell, M. M., Canadell, J., Mooney, H. A., Jackson, R. B., Parson, D., Scholes, R., Sala, O. E., and Trimborn, P.: Downward flux of water through roots (i.e. inverse hydraulic lift) in dry Kalahari sands, Oecologia, 115, 460-462, 1998.

Schymanski, S. J.: Transpiration as the Leak in the Carbon Factory: A Model of Self-Optimising Vegetation, Ph.D. thesis, University of Western Australia, Perth, Australia, http://theses.library.uwa. edu.au/adt-WU2007.0095, 2007.

Schymanski, S. J., Roderick, M. L., Sivapalan, M., Hutley, L. B., and Beringer, J.: A test of the optimality approach to modelling canopy properties and $\mathrm{CO} 2$ uptake by natural vegetation, Plant, Cell Environ., 30, 1586-1598, doi:10.1111/j.1365-3040.2007. 01728.x, http://www.blackwell-synergy.com/doi/abs/10.1111/j. 1365-3040.2007.01728.x, 2007.

Schymanski, S. J., Roderick, M. L., Sivapalan, M., Hutley, L. B., and Beringer, J.: A canopy scale test of the optimal water use hypothesis, Plant Cell Environ., 31, 97-111, doi:10.1111/j.13653040.2007.01740.x, http://www.blackwell-synergy.com/doi/abs/ 10.1111/j.1365-3040.2007.01740.x, 2008.

Silberstein, R., Held, A., Hatton, T., Viney, N., and Sivapalan, M.: Energy balance of a natural jarrah (Eucalyptus marginata) forest 
in Western Australia: measurements during the spring and summer, Agr. Forest Meteorol., 109, 79-104, 2001.

Simunek, J., van Genuchten, M. T., and Sejna, M.: The HYDRUS1D Software Package for Simulating the One-Dimensional Movement of Water, Heat, and Multiple Solutes in VariablySaturated Media, Tech. Rep. Version 3.0, Department of Environmental Sciences, University of California Riverside, California, 2005.

Specht, R. L.: Foliage projective cover and standing biomass, in: Vegetation Classification in Australia, edited by Gillison, A. N. and Anderson, D. J., Commonwealth Scientific and Industrial Research Organization (Australia), Canberra, 1981.

Steudle, E.: Water uptake by plant roots: an integration of views, Plant Soil, 226, 45-56, 2000.

Teuling, A. J., Uijlenhoet, R., Hupet, F., and Troch, P. A.: Impact of plant water uptake strategy on soil moisture and evapotranspiration dynamics during drydown, Geophys. Res. Lett., 33, L03401, doi:10.1029/2005GL025019, 2006.

Unsworth, M. H., Phillips, N., Link, T., Bond, B. J., Falk, M., Harmon, M. E., Hinckley, T. M., Marks, D., and U, K. T. P.: Components and controls of water flux in an old-growth Douglas-firwestern hemlock ecosystem, Ecosystems, 7, 468-481, 2004. van Genuchten, M. T.: A Closed-Form Equation for Predicting the Hydraulic Conductivity of Unsaturated Soils, Soil Sci. Soc. Am. J., 44, 892-898, 1980.

van Wijk, M. T. and Bouten, W.: Towards understanding tree root profiles: simulating hydrologically optimal strategies for root distribution, Hydrol. Earth Syst. Sci., 5, 629-644, 2001, http://www.hydrol-earth-syst-sci.net/5/629/2001/.

Varado, N., Braud, I., and Ross, P. J.: Development and assessment of an efficient vadose zone module solving the 1D Richards' equation and including root extraction by plants, J. Hydrol., 323, 258-275, 2006.

Waring, R. H. and Running, S. W.: Sapwood water storage: its contribution to transpiration and effect upon the water conductance through the stems of old-growth Douglas-fir, Plant, Cell Environ., 1, 131-140, 1978.

Zweifel, R. and Häsler, R.: Dynamics of water storage in mature subalpine Picea abies: temporal and spatial patterns of change in stem radius, Tree Physiol., 21, 561-569, 2001.

Zweifel, R., Item, H., and Häsler, R.: Link between diurnal stem radius changes and tree water relations, Tree Physiol., 21, 869877, 2001. 